\title{
CONTROLE DE INJÚRIAS PELO FRIO EM PÊSSEGOS ‘DOURADO-2’ SUBMETIDOS AO TRATAMENTO TÉRMICO
}

\section{Daniela Cristina Clemente VitTi}

Dissertação apresentada à Escola Superior de Agricultura "Luiz de Queiroz", Universidade de São Paulo, para obtenção do título de Mestre em Ciências, Área de Concentração: Fisiologia e Bioquímica de Plantas.

P I R A C I C A B A

Estado de São Paulo - Brasil

Setembro - 2004 


\section{CONTROLE DE INJÚRIAS PELO FRIO EM PÊSSEGOS ‘DOURADO-2’ SUBMETIDOS AO TRATAMENTO TÉRMICO}

\section{Daniela Cristina Clemente VitTi}

Engenheiro Agrônomo

Orientador: Prof. Dr. RICARDO ALFREDO KLUGE

Dissertação apresentada à Escola Superior de Agricultura “Luiz de Queiroz", Universidade de São Paulo, para obtenção do título de Mestre em Ciências, Área de Concentração: Fisiologia e Bioquímica de Plantas.

P I R A C I C A B A

Estado de São Paulo - Brasil

Setembro - 2004 


\section{Dados Internacionais de Catalogação na Publicação (CIP) DIVISÃO DE BIBLIOTECA E DOCUMENTAÇÃO - ESALQ/USP}

Vitti, Daniela Cristina Clemente

Controle de injúrias pelo frio em pêssego 'Dourado-2' submetidos ao tratamento térmico / Daniela Cristina Clemente Vitti. - - Piracicaba, 2004.

75 p. : il.

Dissertação (Mestrado) - - Escola Superior de Agricultura Luiz de Queiroz, 2004.

Bibliografia.

1. Distúrbios fisiológicos de plantas 2. Pessêgo 3. Lanosidade 4. Tratamento térmico Título

CDD 634.25

"Permitida a cópia total ou parcial deste documento, desde que citada a fonte - O autor" 
Aos meus pais, Maria Aparecida e Godofredo, pela vida, pelo exemplo e pelo amor,

DEDICO.

Ao Marcelo e aos nossos filhos, Naomi e Yuri, pelo amor e pela alegria infinita, 


\section{AGRADECIMENTOS}

Ao Prof. Ricardo Alfredo Kluge, pela oportunidade da realização deste trabalho, pela orientação e pela amizade.

Ao Prof. Ângelo Pedro Jacomino, pela parceria e pela amizade.

À CAPES, Coordernação de Aperfeiçoamento de Pessoal de Nível Superior, pela concessão da bolsa de estudo.

À FAPESP, Fundação de Amparo à Pesquisa do estado de São Paulo, pelo financiamento da pesquisa.

À Profa. Drá. Giuseppina Pace Pereira Lima, pela disposição em ajudar sempre e pela amizade.

Ao Engo ${ }^{\circ}$ Agro. Marcos Kobaiashi, pelo fornecimento dos frutos.

Aos meus amigos de luta: Ilana, Maria Cecília, Carol, Maria Luíza, Vanessa, Flávia, Juan, Cleber, André, Renata, Fabiana, Ana Helena, Raquel, pela amizade e pela sempre disposição em ajudar de todas as maneiras.

Ao Marcos e a Aninha pela disponibilidade sempre.

À Maria das Graças, técnica do laboratório, pela ajuda.

Ao GAPE e a Miriam pela disponibilidade dos computadores e pela ajuda com as análises estatísticas.

À bibliotecária Silvia Zinly pela simpatia e pela revisão da dissertação.

Aos demais amigos, colegas, professores e funcionários, que colaboraram direta ou indiretamente para a realização deste trabalho. 


\section{SUMÁRIO}

Página

RESUMO

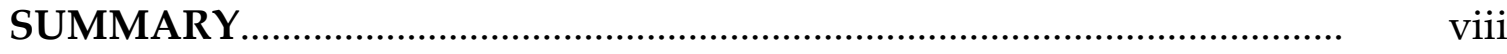

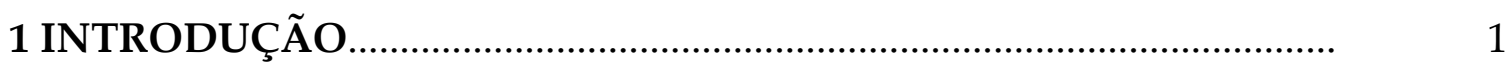

2 REVISÃO DE LITERATURA.................................................................

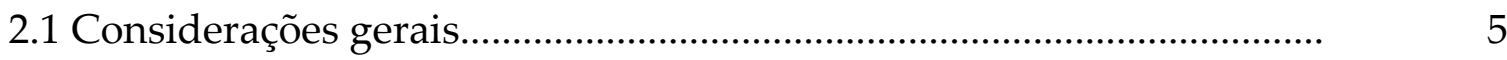

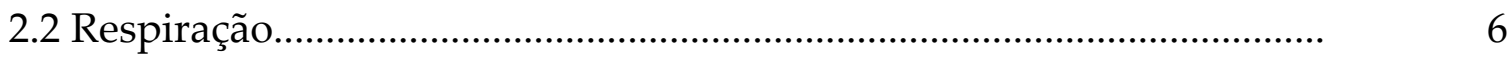

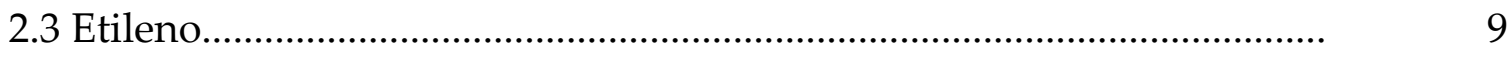

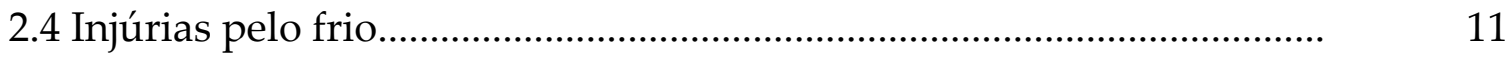

2.5 Lanosidade ............................................................................................

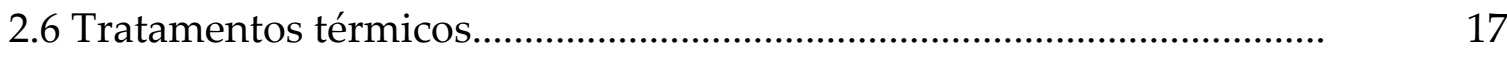

2.6.1 Condicionamento térmico......................................................................... 19

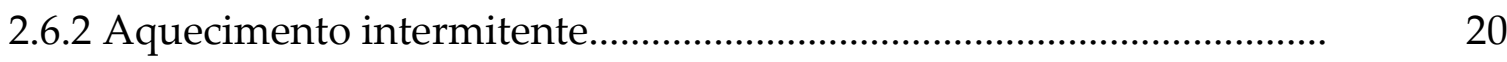

2.7 Efeitos fisiológicos e bioquímicos dos tratamentos térmicos................... 20

3 MATERIAL E MÉTODOS ................................................................... 25

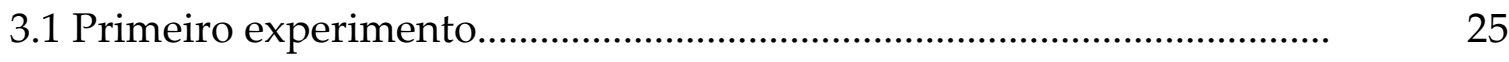

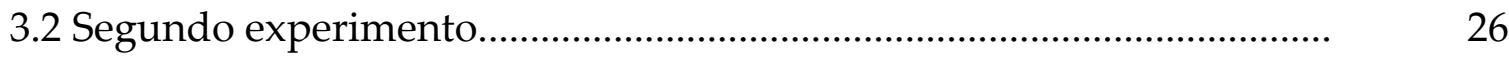

3.3 Armazenamento dos frutos..................................................................... 27

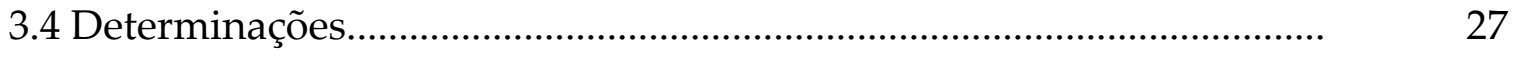

3.5 Delineamento experimental e Análise estatística..................................... 32 


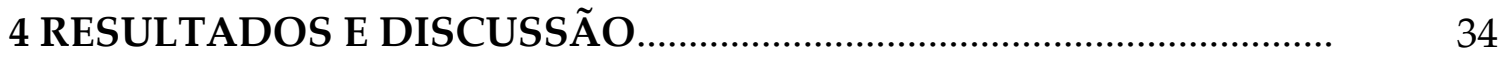

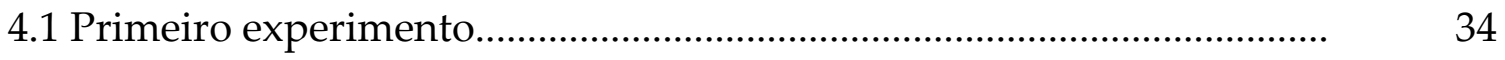

4.2 Segundo experimento....................................................................... 50

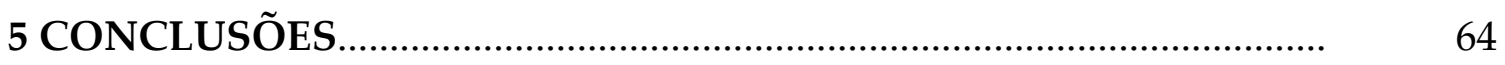

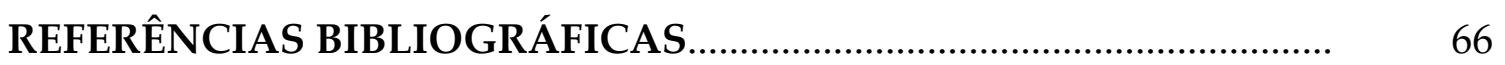




\title{
CONTROLE DE INJÚRIAS PELO FRIO EM PÊSSEGOS 'DOURADO-2’ SUBMETIDOS AO TRATAMENTO TÉRMICO
}

\author{
Autora: DANIELA CRISTINA CLEMENTE VITTI \\ Orientador: Prof. Dr. RICARDO ALFREDO KLUGE
}

\section{RESUMO}

O presente trabalho teve como objetivo verificar o efeito de diversos tratamentos térmicos sobre a incidência de lanosidade em pêssegos 'Dourado$2^{\prime}$ armazenados a $0^{\circ} \mathrm{C}$. Foram realizados dois experimentos. No primeiro, os tratamentos térmicos foram realizados na forma de condicionamento térmico antes da refrigeração, com os frutos sendo expostos a $50^{\circ} \mathrm{C} / 1 \mathrm{~h}$ e $2 \mathrm{~h}$; a $38^{\circ} \mathrm{C} / 24 \mathrm{~h}$ e a $20^{\circ} \mathrm{C} / 48 \mathrm{~h}$, e através do aquecimento intermitente durante o armazenamento refrigerado com frutos aquecidos a cada cinco dias a $25^{\circ} \mathrm{C} / 24 \mathrm{~h}$ e $48 \mathrm{~h}$ e a $15^{\circ} \mathrm{C} / 24 \mathrm{~h}$ e $48 \mathrm{~h}$; frutos aquecidos a cada dez dias a $15^{\circ} \mathrm{C}$ e $25^{\circ} \mathrm{C} / 48 \mathrm{~h}$ e a $38^{\circ} \mathrm{C} / 24 \mathrm{~h}$. No segundo experimento, os melhores tratamentos foram repetidos: condicionamento térmico antes da refrigeração, com os frutos sendo expostos a $50^{\circ} \mathrm{C} / 2 \mathrm{~h}$ e a $20^{\circ} \mathrm{C} / 48 \mathrm{~h}$, e aquecimento intermitente durante o armazenamento refrigerado com frutos aquecidos a cada cinco dias a $25^{\circ} \mathrm{C} / 24 \mathrm{~h}$ e a cada dez dias a $25^{\circ} \mathrm{C} / 48 \mathrm{~h}$. Após 30 dias de armazenamento e mais 3 dias de comercialização 
simulada, foram determinados os efeitos dos tratamentos sobre a qualidade do fruto: incidência de lanosidade, podridões, teor de sólidos solúveis, acidez titulável, teor de vitamina $\mathrm{C}$, coloração, firmeza da polpa. Além disso, foi realizada análise sensorial no primeiro experimento, e determinação da taxa respiratória e de liberação de etileno no segundo. Foi observado que, de modo geral, o aquecimento intermitente se mostrou mais eficaz do que o condicionamento térmico no que se refere ao controle da lanosidade, com exceção do aquecimento a cada 5 dias a $25^{\circ} \mathrm{C} / 48 \mathrm{~h}$, onde observou-se elevada incidência de podridões. $\mathrm{O}$ aquecimento intermitente com ciclos de 5 ou 10 dias e o condicionamento térmico a $20^{\circ} \mathrm{C} / 48 \mathrm{~h}$ podem ser utilizados para reduzir a incidência de lanosidade em pêssegos 'Dourado-2' armazenados durante 30 dias a $0^{\circ} \mathrm{C}$. 


\title{
CONTROL OF CHILLING INJURY IN ‘DOURADO-2’ PEACHES SUBMITTED TO HEAT TREATMENT
}

\author{
Author: DANIELA CRISTINA CLEMENTE VITTI \\ Adviser: Prof. Dr. RICARDO ALFREDO KLUGE
}

\section{SUMMARY}

The present research was carried out with the objective to verify the effect of heat treatments on the incidence of woolliness in 'Dourado-2' peaches cold stored at $0^{\circ} \mathrm{C}$. Two experiments were carried out. In the first, heat treatments were applied as conditioning temperature $\left(50^{\circ} \mathrm{C} / 1 \mathrm{~h}\right.$ and $2 \mathrm{~h} ; 38^{\circ} \mathrm{C} / 24 \mathrm{~h}$ and $20^{\circ} \mathrm{C} / 48 \mathrm{~h}$ ) and as intermittent warming during cold storage. In these treatments fruit were warmed each five days at $25^{\circ} \mathrm{C} / 24 \mathrm{~h}$ and $48 \mathrm{~h}$, and at $15^{\circ} \mathrm{C} / 24 \mathrm{~h}$ and $48 \mathrm{~h}$, and each ten days at $15^{\circ} \mathrm{C}$ e $25^{\circ} \mathrm{C} / 48 \mathrm{~h}$ and at $38^{\circ} \mathrm{C} / 24 \mathrm{~h}$. In the second experiment, the best four treatments (plus control treatment) from first experiment were replicated: conditioning at $50^{\circ} \mathrm{C} / 2 \mathrm{~h}$ and $20^{\circ} \mathrm{C} / 48 \mathrm{~h}$, and intermittent warming each five days at $25^{\circ} \mathrm{C} / 24 \mathrm{~h}$ and each ten days at $25^{\circ} \mathrm{C} / 48 \mathrm{~h}$. After 30 days of storage at $0^{\circ} \mathrm{C}$ (plus 3 days at room temperature) the effect of treatments on fruit quality was evaluated. The variables evaluated were: incidence of woolliness and decay, soluble solids content, acidity, vitamin C (ascorbic acid), skin color and firmness. Besides, sensorial analysis was 
evaluated in the first experiment and the respiratory rate and ethylene production in the second experiment. In general, the intermittent warming was more efficient than conditioning in relation incidence of woolliness, with exception to the intermittent warming each five days at $25^{\circ} \mathrm{C} / 48 \mathrm{~h}$ that have presented high incidence of decay. The intermittent warming with cycles of five or 10 days and the conditioning temperature at $20^{\circ} \mathrm{C} / 48 \mathrm{~h}$ can be used to reduce incidence of woolliness in 'Dourado-2' peaches cold stored at $0^{\circ} \mathrm{C}$ during 30 days. 


\section{INTRODUÇÃO}

O Brasil apresenta altos níveis de perdas pós-colheita, sendo que, segundo estimativas, entre 30 a $40 \%$ da produção anual de frutos e hortaliças deixam de ser consumidas no país devido à estas perdas (FNP Consultoria \& Comércio, 2000). Vários fatores contribuem para este quadro desalentador, incluindo colheita e transporte inadequados, falta da cadeia de frio ou utilização inadequada da mesma, embalagens inapropriadas, entre outros.

Os frutos do pessegueiro (Prunus persica (L). Batsch), por suas características fisiológicas e bioquímicas, são altamente perecíveis, o que não impede sua difusão em diversas zonas do mundo nem o interesse dos geneticistas em conseguir novas variedades (Fernandez, 2000).

Considerando que o pêssego tem vida pós-colheita muito curta e a cada dia o consumidor torna-se mais exigente quanto à qualidade, alguns atributos devem ser levados em consideração quando se pretende avaliar sua qualidade. Entre eles estão: aparência (tamanho, forma, ausência de defeitos e cor), sabor e odor ("flavor"), valor nutritivo e textura. Grande parte destes atributos sofre modificações físico-químicas e bioquímicas na pós-colheita. Assim, é necessário o conhecimento da fisiologia do fruto para a redução da atividade metabólica, como forma de evitar a perda de massa e da textura, e as alterações na aparência, no "flavor" e no valor nutritivo (Nunes, 2003). 
As principais causas da perda de qualidade pós-colheita em pêssegos estão relacionadas com o próprio metabolismo, danos mecânicos, perda da firmeza de polpa, ocorrência de distúrbios fisiológicos e podridões. Estas perdas são influenciadas por características varietais, pelas condições de manejo, de colheita, e pelo sistema e condições de armazenamento (Lill et al., 1989, Lelièvre et al., 1997).

A redução das perdas pós-colheita é importante tanto do ponto de vista econômico quanto científico. Atualmente, é preferível esforço na melhoria das técnicas de conservação pós-colheita do que perseguir incremento na produção, pois assim se consegue maiores benefícios dos recursos aplicados.

Considerando que a tendência dos mercados mundiais de frutos aponta para um cenário onde cada vez mais é valorizado o aspecto qualitativo do fruto, é fundamental profundo conhecimento do comportamento fisiológico dos frutos, permitindo assim manipulação cada vez mais precisa, visando à manutenção da qualidade pelo maior período de tempo possível.

Devido ao fato de que a maioria dos tratamentos químicos aplicados com o propósito de reduzir as perdas pós-colheita são potencialmente prejudiciais ao homem e ao ambiente, e de que há maior consciência da população sobre a importância do consumo de alimentos saudáveis na prevenção de doenças e na melhoria da qualidade de vida, o seu uso está sendo progressivamente limitado ou proibido. Assim, atualmente, existe crescente interesse por tratamentos físicos alternativos ou com produtos atóxicos.

A refrigeração tem sido a principal técnica utilizada para preservar a qualidade dos produtos hortifrutícolas recém colhidos, reduzindo a velocidade de reações químicas responsáveis pelas alterações no fruto durante o 
amadurecimento. Entretanto, em alguns casos, somente baixas temperaturas podem ser insuficientes para retardar as mudanças na qualidade do produto colhido. Além disso, a refrigeração quando aplicada por períodos prolongados pode conduzir ao aparecimento de injúrias causadas pelo frio, cujos sintomas normalmente aumentam durante a fase de comercialização, isto é, após a retirada do produto da condição refrigerada.

Em pêssegos, tem sido verificado para a cultivar Dourado-2, uma das mais importantes para o Estado de São Paulo, a presença de lanosidade, desordem associada com o armazenamento do fruto em baixa temperatura (0$1^{\circ} \mathrm{C}$ ). Esta desordem torna o fruto sem sucosidade, diminuindo sensivelmente a sua aceitação e dificultando o aumento da vida útil do mesmo.

Com o objetivo de manter os benefícios da refrigeração e evitar as injúrias pelo frio, técnicas complementares vêm sendo testadas. Dentre essas técnicas tem-se os tratamentos térmicos, aplicados na forma de condicionamento em temperatura alta ou moderada antes da refrigeração e o aquecimento intermitente, aplicado durante a refrigeração. Em nível comercial, esses métodos têm sido pouco utilizados, devido ao baixo conhecimento dos procedimentos de aplicação e do potencial de aumento de conservação em relação ao armazenamento convencional. Adicionalmente, os efeitos desses tratamentos sobre a fisiologia, bioquímica e a qualidade do produto têm sido pouco estudados e, uma vez estabelecidos, podem permitir identificar processos metabólicos possíveis de manipulação, proporcionado assim a criação de tecnologias de armazenamento que permitam a ampliação no período de conservação e comercialização de frutos. 
O presente trabalho teve por objetivo determinar o efeito dos tratamentos térmicos nas formas de aquecimento intermitente $\mathrm{e}$ condicionamento térmico sobre qualidade e o desenvolvimento dos sintomas de injúrias pelo frio em pêssegos 'Dourado-2' e determinar o efeito dos tratamentos térmicos sobre o processo respiratório e liberação de etileno dos frutos durante o período de armazenamento e comercialização simulada. 


\section{REVISÃO DE LITERATURA}

\subsection{Considerações Gerais}

O pêssego (Prunus persica (L.) Batsch) pertence à família Rosaceae, subfamília Prunoidea e gênero Prunus. Faz parte do diversificado grupo denominado frutos de caroço, que se caracteriza por apresentar endocarpo lignificado, rodeado de polpa ou mesocarpo. No gênero Prunus, os frutos apresentam uma característica em comum que é a presença de sutura no plano longitudinal, mais ou menos pronunciada de acordo com a cultivar (Brady, 1993).

Os pêssegos são muito apreciados por suas qualidades gustativas e estéticas, sendo consumidos frescos ("in natura") ou após processamento, principalmente como conservas ou geléias. Quando comparado a outros frutos quanto ao aspecto nutricional, apresenta valores relativamente elevados de $\mathrm{K}$, $\mathrm{Mg}$, vitamina A, B2, porém baixos valores de cálcio e vitamina $\mathrm{C}$.

O consumo de pêssegos no Brasil ainda é muito pequeno, totalizando apenas $0,85 \mathrm{~kg} / \mathrm{habitante} / \mathrm{ano}$. Este baixo consumo é explicado, em grande parte, pelo reduzido poder aquisitivo da população e também pela falta de investimentos em propaganda e em esclarecimentos ao consumidor, que considera o pêssego ainda como uma sobremesa, quando deveria considerá-lo também como um complemento alimentar (Nunes, 2003). 
A produção brasileira de pêssegos está totalmente concentrada no Sul e Sudeste do país, sendo o Rio Grande do Sul, Santa Catarina e São Paulo os maiores produtores (FNP Consultoria \& Comércio, 2004).

De acordo com a classificação comercial das variedades, é importante considerar a adesão ou não da polpa ao caroço, a cor da polpa e a época de maturação. A Dourado-2 é uma cultivar de tamanho grande, bela aparência, polpa amarela, vistosa, de textura firme e, ao mesmo tempo sucosa, com ligeira auréola circundando o caroço, que é tamanho médio a pequeno e solto. Externamente, apresenta uma epiderme de coloração amarela com manchas avermelhadas, qualidade excelente, com sabor doce-acidulado agradável: teor de açúcares ao redor de 15 Brix e acidez pH 4,0. (Ojima et al., 1985; Bron, 2002).

\subsection{Respiração}

A respiração é um processo biológico essencial para a liberação da energia necessária à maturação dos frutos. Durante este processo, compostos orgânicos reduzidos, como polissacarídeos, açúcares simples, ácidos orgânicos, proteínas e lipídeos, são mobilizados e subsequentemente oxidados em $\mathrm{CO}_{2} \mathrm{e}$ $\mathrm{H}_{2} \mathrm{O}$ (Awad, 1993; Taiz \& Zeiger, 1998). Desta forma, o fruto consegue continuar realizando suas funções vitais, mesmo depois da colheita, utilizando as reservas acumuladas durante o crescimento e maturação (Kluge et al., 2002).

A respiração nos frutos segue as rotas metabólicas comuns em qualquer tecido vegetal: glicólise, ciclo dos ácidos tricarboxílicos e cadeia transportadora de elétrons, estando associada também à via das pentoses fosfato. Os substratos da respiração em frutos são principalmente os açúcares, ácidos orgânicos e lipídeos acumulados durante o desenvolvimento (Tucker, 1993). Durante a 
respiração estas substâncias são oxidadas em moléculas mais simples $\left(\mathrm{CO}_{2}\right.$ e $\left.\mathrm{O}_{2}\right)$, com produção de energia e esqueleto carbônico que podem ser utilizados em reações de síntese. A energia liberada está sob duas formas: calor e ATP (Wills et al., 1998).

O processo respiratório é fundamental no amadurecimento dos frutos, pois várias reações acopladas a esse processo são responsáveis pela síntese de inúmeros compostos, tais como pigmentos, compostos fenólicos e hormônios vegetais.

Quando um fruto alcança a maturidade, sua taxa respiratória pode continuar constante ou diminuir lentamente, à medida que o fruto torna-se senescente. Contrariamente a este comportamento, um marcante aumento na taxa respiratória, conhecido como climatério, acompanha o amadurecimento de muitos frutos. $\mathrm{O}$ amadurecimento e o aumento climatérico são gatilhos para a produção endógena de etileno (Taiz \& Zeiger, 1998).

O padrão respiratório exibido pelos frutos após a colheita é o fator determinante da longevidade do mesmo, e de acordo com este padrão, os frutos são classificados em climatéricos e não climatéricos (Kluge et al., 2002).

Nos frutos não climatéricos a respiração diminui durante $\mathrm{o}$ amadurecimento e as transformações bioquímicas que tornaram o fruto maduro ocorrem de forma mais lenta. $\mathrm{O}$ amadurecimento só ocorre se o fruto estiver ainda ligado à planta, diferentemente dos frutos climatéricos que possuem a capacidade de amadurecer mesmo após a colheita, desde que colhidos no grau de maturação adequado (Wills et al., 1998).

Pêssegos são frutos climatéricos, cujo processo de amadurecimento é tipicamente caracterizado por duas fases: primeiro um ligeiro amolecimento e 
depois pronunciada perda de firmeza provocada por mudanças estruturais na parede celular e lamela média (Orr \& Brady, 1993). Por esta razão, os frutos são colhidos no estádio pré-climatérico de forma que possam resistir ao manuseio. Em muitos casos, estes frutos não alcançam o máximo do "flavor" e aroma depois de colhidos, pois são colhidos precocemente.

Independente da classificação dos frutos, a respiração é o principal processo fisiológico que continua ocorrendo após a colheita e é um indicador da atividade metabólica determinando a vida útil no armazenamento.

A temperatura, a composição atmosférica (concentração de $\mathrm{CO}_{2}, \mathrm{O}_{2}$ e etileno) e estresse, são os principais fatores externos que afetam a respiração (Kluge et al., 2002).

As reações enzimáticas envolvidas na respiração são governadas pela temperatura, fator individual do armazenamento mais importante na manutenção da qualidade dos frutos. Para cada $10^{\circ} \mathrm{C}$ de aumento na temperatura, a taxa respiratória aproximadamente dobra ou triplica. A mudança na taxa segue a Lei de Vant Hoff, a qual exprime que a taxa das reações químicas e bioquímicas aumenta de 2 a 3 vezes com o aumento de calor gerado. Portanto, a diminuição da temperatura no armazenamento é de vital importância para retardar a respiração (Handenburg et al., 1986).

A taxa respiratória do fruto em amadurecimento é aumentada pela exposição a altas temperaturas (Klein e Lurie, 1990; Lurie e Klein, 1991; Mitchan e McDonald, 1993), e a resposta à temperatura varia com a idade fisiológica do tecido (Paull e Chen, 2000). 


\subsection{Etileno}

$\mathrm{O}$ etileno $\left(\mathrm{C}_{2} \mathrm{H}_{4}\right)$ é um hormônio vegetal envolvido na aceleração do amadurecimento e senescência de frutos climatéricos, e pode promover diferentes respostas em função do estádio de desenvolvimento, das condições ambientais e da espécie ou mesmo da variedade (Lelièvre, 1997).

Todos os frutos que amadurecem em resposta ao etileno, exibem um aumento respiratório característico denominado de climatério. Estes frutos também exibem um pico na produção de etileno imediatamente após o pico respiratório.

Quase todas as partes das plantas superiores podem produzir etileno, embora a taxa de produção dependa do tipo de tecido e do estádio de desenvolvimento. Em geral, regiões meristemáticas e nodais são as mais ativas na biossíntese de etileno. Entretanto, a produção de etileno também aumenta durante a abscisão de folhas e a senescência de flores, assim como no amadurecimento de frutos. Todos os tipos de ferimentos podem induzir a síntese de etileno, assim como estresse fisiológico, injúrias pelo frio, seca, excesso de água, doenças e temperatura (Taiz \& Zeiger, 1998).

O mecanismo de ação do etileno consiste na sua ligação a uma molécula receptora, provavelmente uma proteína (ETR1), que possui um sítio de ligação do hormônio vegetal ou, o que parece mais provável, uma via de sinalização formada por mensageiros secundários vão ao núcleo da célula e induzem a expressão gênica (transcrição). Consequentemente há formação de novos RNAs e novas proteínas, desencadeando um processo de reação em cascata (Kluge et al., 2002), que levam à modificação da expressão gênica, com conseqüentes respostas fisiológicas e bioquímicas (Leliévre, 1997). 
Partindo deste princípio, a inibição da ligação do etileno ao seu receptor pode reduzir a produção autocatalítica e a ação do mesmo e, com isso, retardar o amadurecimento e a senescência dos frutos climatéricos.

O controle da ação e da biossíntese de etileno é feito de várias formas, sendo uma prática comum na pós-colheita, que tem como objetivo o prolongamento da vida do vegetal. Atmosferas modificadas com baixos teores de $\mathrm{O}_{2}$ e altos teores de $\mathrm{CO}_{2}$ e o uso de baixas temperaturas são técnicas usadas em pós-colheita para diminuir a biossíntese de etileno. A biossíntese de etileno pode também ser inibida pela aplicação de compostos como AVG (aminoetoxivinilglicina) e o AOA (ácido aminoxiacético), ambos inibem a ação da enzima ACC sintase, responsável pela conversão do SAM para ACC (Yang, 1985; Kanellis et al., 1991; John, 1997).

O etileno é biologicamente ativo em quantidades traço $\left(0,005 \mu \mathrm{L} \mathrm{L}^{-1}\right)$, e a concentração necessária para induzir o amadurecimento na fase pré-climatérica é dependente da espécie e estádio de maturação dos frutos (Abeles, et al., 1992).

A maioria das alterações fisiológicas pós-colheita de frutos climatéricos é influenciada, direta ou indiretamente, pelo etileno. Em vários trabalhos tem sido demonstrado que a redução da produção e/ou da ação do etileno pode prolongar o período de conservação dos frutos. (Lelièvre et al., 1997). Para a maioria dos frutos o efeito é positivo (Sisler et al., 1997; Fan et al., 1999; Zhou et al., 2001). Entretanto, em alguns casos, onde testou-se a redução da produção e da ação com a aplicação de 1-metilciclopropeno (1-MCP), um potente inibidor da ação do etileno (Sisler et al., 1997), os resultados indicaram efeitos negativos (Dong et al., 2001; Zhou et al., 2001). Em frutos sensíveis à ocorrência de 
lanosidade, a redução da produção e/ou da ação do etileno tem efeito negativo, induzindo a formação da lanosidade (Dong et al., 2001).

A síntese de etileno é reversivelmente inibida com altas temperaturas (Biale, 1960; Field, 1984). Frutos expostos por longos períodos à altas temperaturas, rapidamente restabelecem sua habilidade de sintetizar etileno (Dunlap et al., 1990). De acordo com Yu et al. (1980), a conversão de ACC a etileno é aparentemente suscetível ao dano pelo calor (temperaturas maiores que $30^{\circ} \mathrm{C}$ ). Há rápida perda da atividade da $\mathrm{ACC}$ oxidase em mamão papaia (75\%) e outros frutos expostos por curtos períodos a temperaturas maiores que $40^{\circ} \mathrm{C}$ (Chan et al., 1988; Dunlap et al., 1990; Klein e Lurie, 1990; Paull e Chen, 1990; Ketsa et al., 1999).

\subsection{Injúrias pelo frio}

A desordem mais importante do ponto de vista da qualidade interna, e que afeta diretamente o valor comercial e de consumo em muitas espécies, é o denominado dano por frio e/ou colapso interno, ou adaptando diretamente do idioma inglês, "chilling injury" e "internal breakdown".

As injúrias pelo frio constituem as desordens fisiológicas mais comuns e preocupantes em produtos hortícolas armazenados, sendo fator limitante na vida útil de pêssegos armazenados a baixas temperaturas (Lill et al., 1989; Luza et al., 1992; Artés et al., 1996). Ocorrem quando os produtos são expostos a temperaturas inferiores à temperatura mínima de segurança (TMS), mas acima do ponto de congelamento. A TMS é variável para os diferentes produtos, na faixa de 0 a $15^{\circ} \mathrm{C}$, e define a temperatura abaixo da qual os danos podem

ocorrer, dependendo do tempo de exposição. Mesmo não provocando o congelamento das células, a exposição do fruto à temperaturas baixas por um 
determinado período de tempo pode causar uma série de modificações no metabolismo normal, os quais reduzem a sua qualidade (Bron, 2002).

Nos frutos em geral, os sintomas das injúrias pelo frio podem se manifestar como escurecimento interno, depressões superficiais, falha no amadurecimento, polpa translúcida, falha no desenvolvimento normal da cor da polpa e, normalmente, uma completa perda de odor e sabor característicos. Em frutos de caroço, a injúria pelo frio ocorre com maior intensidade nas temperaturas entre 2,2 e $7,8^{\circ} \mathrm{C}$. Os sintomas também se manifestam com armazenamento a $0^{\circ} \mathrm{C}$ ou menos, mas ocorrem mais lentamente e são menos severos do que em temperaturas mais elevadas (Kluge et al., 2002).

Muitas variedades de pêssegos, nectarinas e ameixas, quando armazenadas sob baixa temperatura, apresentam desordens internas ("internal breakdown"), que podem limitar o tempo em que o fruto pode ser mantido sob refrigeração e ainda assim amadurecer normalmente (Mitchell et al., 1974).

Em pêssegos, temperaturas em torno de 2,5 $5^{\circ} \mathrm{C}$ (Von Mollendorf \& De Villiers, 1988 a, b) normalmente aumentam as injúrias pelo frio, embora esta desordem seja fortemente dependente da cultivar e do ponto de colheita (Boyes, 1955; Artés et al., 1996).

O ponto de colheita dos frutos é fator importante no desenvolvimento das injúrias causadas pelo frio. Ele está relacionado com o destino que se deseja dar ao fruto colhido, ou seja, pêssegos colhidos em estádios menos avançados de maturação preservam a firmeza de polpa, mas aumentam a ocorrência de problemas fisiológicos quando armazenados, apresentando também baixa qualidade sensorial. Por outro lado, frutos colhidos tardiamente, melhoram a 
qualidade sensorial (gosto e aroma), porém são mais sensíveis no transporte e apresentam baixo período de conservação.

Salunkhe \& Desai (1984) afirmam que frutos colhidos "verdes" ou "de vez" (maturação fisiológica) apresentam sintomas de "chilling injury" quando armazenados a temperaturas inferiores a $8^{\circ} \mathrm{C}$. Já os frutos maduros são mais resistentes ao "chilling", mas são mais suscetíveis ao ataque de fungos, principalmente quando estocadas a temperaturas superiores a $11^{\circ} \mathrm{C}$.

Frutos verdes de manga são mais suscetíveis às injúrias pelo frio do que frutos mais maduros, os quais podem ser mantidos em temperaturas muito menores (Whangchai et al., 2000). Pepinos 'Sweet Long' colhidos verdes tiveram uma redução de 3 semanas no armazenamento, comparado com os colhidos maduros, cujo armazenamento foi reduzido em 1 semana (Martínez-Romero, 2003).

Pêssegos e nectarinas menos maduros são freqüentemente mais suscetíveis às injúrias causadas pelo frio. Pêssegos colhidos no estádio maduro e firme frequentemente amadurecem satisfatoriamente a $20^{\circ} \mathrm{C}$ e atingem qualidade comestível (Fernández-Trujillo e Artés, 1998; Fernández-Trujillo et al., 2000). Pêssegos 'Chiripá' colhidos com cor de fundo verde opaca e firmeza de polpa na faixa de 18 a $16 \mathrm{Lbs} \mathrm{pol}^{-2}$ manifestaram altos índices de lanosidade quando mantidos em armazenamento refrigerado por 21 dias e 72 horas em temperatura ambiente. A cultivar Califórnia O'Henry desenvolve os sintomas após 2 semanas a $5^{\circ} \mathrm{C}$ (Crisosto, 2002)

A ocorrência da injúria pelo resfriamento em frutos é o resultado do desequilíbrio entre o acúmulo e o colapso de substâncias tóxicas nas células, ou 
seja, em temperaturas críticas, o acúmulo de substâncias tóxicas é mais rápido do que sua degradação, danificando os tecidos (Ben-Aire et al., 1970).

As respostas primárias de frutos injuriados pelas baixas temperaturas têm sido consideradas como de natureza física, incluindo fenômenos de alteração na porção lipídica das membranas e disfunções das proteínas ligadas às mesmas. Essas alterações conduzem a diversas conseqüências indesejáveis no metabolismo, que incluem extravasamento de solutos, elevação na respiração, acúmulo de toxinas, desbalanço metabólico, perda de compartimentação, perda da integridade da membrana, desenvolvimento de sintomas, incremento na produção de etileno, desorganização ultra-estrutural, parada do fluxo protoplasmático, redução no suprimento e uso de energia, decréscimo na atividade oxidativa mitocondrial, aumento na energia de ativação das enzimas ligadas à membrana; entre outras (Shewfelt, 1993; Wang, 1993).

Várias mudanças fisiológicas e bioquímicas ocorrem em resposta ao estresse causado por "chilling", como aumento nos níveis de poliaminas. É possível que as poliaminas estejam envolvidas na redução das injúrias pelo frio, especialmente com acúmulo de putrescina durante o estresse. Pesquisas anteriores mostraram que níveis de poliaminas endógena estavam relacionados com a resposta do tecido a este estresse pelo aumento de putrescina em citros, cherimóia e abobrinha. Entretanto, resultados controversos têm sido encontrados em várias espécies. Em pêssegos, tem sido sugerido que um aumento em espermidina pode ser conseqüência de "chilling injury" (MartinezRomero, et al., 2003). Whangchai et al. (2000), estudando a suscetibilidade de mangas às injurias pelo frio, sugeriram que é possível estabelecer uma relação entre o acúmulo de poliaminas e o grau de injúrias pelo frio, mas que somente o 
órgão ou tecido suscetível à injúria pelo frio pode manifestar esta tendência. Níveis de putrescina livre aumentaram juntamente com as injúrias pelo frio em pimenta, abobrinha, laranja, lima, limão e "grapefruit". Estes resultados confirmam que o acúmulo de putrescina e/ou espermidina e espermina nos tecidos parece ser uma resposta do fruto as injúrias pelo frio (Martinez-Romero, et al., 2003).

\subsection{Lanosidade}

A suscetibilidade de pêssegos às injúrias pelo frio varia de acordo com a genética, com a maturidade e com os fatores de campo (Crisosto et al., 2002), sendo que os sintomas destas desordens aparecem após duas ou três semanas de armazenamento sob temperaturas acima do ponto de congelamento $\left(-0,5^{\circ} \mathrm{C}\right)$ e inferiores a $10^{\circ} \mathrm{C}$ (Lill et al., 1989). As características principais destas injúrias são a falta de sucosidade (lanosidade ou "woolliness") e o escurecimento da polpa ("internal browning") (Kluge et al., 1996). Como esta desordem não é aparente externamente, os frutos são comercializados, o que pode levar a uma diminuição no consumo (Zhou et al., 2000b).

A lanosidade é um dos primeiros sintomas de dano por frio e tem limitado a comercialização de frutos entre países próximos, como Chile e Estados Unidos, onde a distância entre os portos é considerada pequena, entre 12 e 14 dias (Luchsinger, 2000).

Apesar da aparência externa normal, além da lanosidade, ou seja, textura farinhenta e falta de suco, os pêssegos também apresentam outros sintomas de injúrias pelo frio como a perda de sabor, descoloração, particularmente em torno do caroço, e perda da habilidade de amadurecer 
(Luza et al., 1992; Kailasapathy e Melton, 1992; Wang, 1993). Isto diminui sensivelmente a aceitação do fruto no mercado e dificulta o aumento da vida útil do mesmo.

Além da dificuldade em se detectar a desordem externamente, os sintomas somente são identificados após a remoção do fruto do armazenamento refrigerado, mas, em casos severos, pode-se identificar a presença da lanosidade pela compressão da epiderme, a qual fica emborrachada. Este período de tempo entre o início da desordem causada pelo frio e o desenvolvimento dos sintomas é chamado de período de latência (Fernández-Trujillo e Artés, 1998).

Fisiologicamente, o genótipo sensível à injúria pelo frio apresenta maior taxa respiratória, entretanto não foram observadas diferenças na produção de etileno entre cultivares sensíveis e resistentes (Brovelli et al., 1998). Os mesmos autores assinalaram que as cultivares propensas a desenvolver lanosidade produzem menor quantidades de etileno, mas que a taxa de produção do mesmo é um melhor indicativo da época da colheita do que da existência de lanosidade (Brovelli et al., 1999).

A lanosidade tem uma base genética e as cultivares diferem muito em relação ao tempo que o fruto pode ficar armazenado antes de desenvolver a desordem. Esta diferença na suscetibilidade é um fator primário que determina quanto tempo o fruto permanece comercializável após a colheita (Obenland, 2003).

As pesquisas sobre as causas bioquímicas da lanosidade têm se focado, primeiramente nas diferenças relativas das sustâncias pécticas que são observadas em extratos de parede celular de frutos lanosos ou não. Os frutos lanosos contêm uma grande proporção de material péctico insolúvel com maior 
peso molecular e menor grau de esterificação do que frutos não lanosos. A pectina, nesta forma, retém a água livre do tecido e produz a textura seca característica. $\mathrm{O}$ armazenamento refrigerado para frutos de caroço também resulta na redução da atividade da poligalacturonase (PG), uma enzima chave envolvida na despolimerização e na solubilização da pectina. A perda da atividade da PG, combinada com a deesterificação da pectina promovida pela pectinametilesterase (PME), conduz ao acúmulo de compostos pécticos formadores de gel. Em pêssegos, o acúmulo de RNAm de PG é abundante nos cultivares suscetíveis à lanosidade e não nos não-suscetíveis, sugerindo que a PG pode contribuir para a lanosidade da polpa (Hayama, 2003).

Bron (2002) estudando os efeitos da temperatura sobre as características anatômicas de pêssegos 'Dourado-2', verificou que após 14 e 21 dias de armazenamento refrigerado a $3^{\circ} \mathrm{C}$, mais comercialização simulada, foi possível verificar o acúmulo de substâncias pécticas nos espaços intercelulares e no interior das células parenquimáticas.

Portanto, a causa da lanosidade não está relacionada com a desidratação, e sim com a retenção de água no fruto. O problema está ligado com os mecanismos de liberação de suco, ocasionado pela baixa atividade da enzima poligalacturonase (PG) e uma constante atividade da pectinametilesterase (PME) (Zhou et al., 2000a).

\subsection{Tratamentos térmicos}

A temperatura de armazenamento pode atenuar ou agravar certas desordens fisiológicas. Baixa temperatura de armazenamento é benéfica porque as taxas de respiração e metabolismo são reduzidas. Entretanto, baixas 
temperaturas não suprimem todos os processos metabólicos na mesma extensão. Algumas reações são sensíveis à baixa temperatura e cessam completamente abaixo de uma temperatura crítica. Desta forma, pode ocorrer desequilíbrio no metabolismo, levando ao colapso das células e manifestação de distúrbios fisiológicos (Wills et al., 1981).

Atualmente, não existe nenhum método capaz de evitar completamente os danos de frio. O método básico de controle consiste no armazenamento dos produtos em temperaturas adequadas, ou seja, acima da TMS. Porém, este procedimento pode não ser eficaz para longos períodos de armazenamento, situação em que os sintomas de injúrias pelo frio também podem se manifestar, o que é comumente verificado em frutos de clima temperado (Kluge et al., 2002). Assim, alternativas vêm sendo testadas visando diminuir ou aliviar os danos de frio.

As técnicas utilizadas reduzem os danos através do retardamento no desenvolvimento dos sintomas ou pelo aumento da tolerância do produto ao frio. Dentre estas técnicas destacam-se os tratamentos térmicos, realizados na forma de condicionamento térmico e aquecimento intermitente, realizado durante a refrigeração.

Em nível comercial, estes métodos têm sido pouco aplicados, devido ao baixo conhecimento dos procedimentos de aplicação, embora exista grande potencial de conservação em relação ao armazenamento convencional. Adicionalmente, os efeitos desses tratamentos sobre a fisiologia, bioquímica e a qualidade do produto têm sido pouco estudados e, uma vez estabelecidos, podem permitir identificar processos metabólicos possíveis de manipulação, 
proporcionando, assim, a criação de tecnologias de armazenamento que permitam a ampliação no período de conservação e comercialização de frutos.

Os tratamentos térmicos em frutos são usados para desinfecção de insetos, controle de doenças, para modificar a resposta dos frutos a outros tipos de estresses e manter a qualidade durante a armazenagem (Paull \& Chen, 2000).

\subsubsection{Condicionamento Térmico}

O condicionamento térmico consiste em expor os frutos a temperaturas moderadas ou elevadas, por curtos períodos, antes de refrigerá-los. O uso desta técnica resulta, basicamente, nas seguintes implicações: retardamento no amadurecimento de frutos climatéricos, devido à redução na síntese de etileno e na atividade de enzimas que degradam a parede celular, diminuição dos danos causados pelas baixas temperaturas e redução de podridões (Klein \& Lurie, 1991; Kluge et al., 2002).

$\mathrm{O}$ condicionamento em temperatura moderada $\left(15-25^{\circ} \mathrm{C}\right)$ reduziu as injúrias pelo frio em mamão, manga, pimentão, abobrinha e limão (Kluge et al., 2002).

$\mathrm{O}$ condicionamento em altas temperaturas $\left(30\right.$ a $60^{\circ} \mathrm{C}$ ) por curtos períodos mostrou ser eficiente para diminuir as injúrias pelo frio em melancia, mamão (Chan, 1988), abobrinha, maçã (Lurie \& Klein, 1990), tomate (Lurie \& Klein, 1991), pêssego (Nanos \& Mitchell, 1991; Li-Ping \& Tao, 1998), pepino (McCollum et al., 1993), tangerina, abacate (Woolf, 1997) e pimentão (GonzálezAguilar et al., 2000). 


\subsubsection{Aquecimento Intermitente}

O aquecimento intermitente consiste na interrupção da baixa temperatura de armazenamento, por um ou mais períodos de alta temperatura. Esse tratamento deve ser realizado antes dos danos tornarem-se irreversíveis, o que varia de acordo com o produto (Kluge et al., 2002). Foi verificada eficiência no controle de injúrias pelo frio com a aplicação do aquecimento intermitente em limão, tomate (Artés \& Escriche, 1994; Kluge et al., 1998), pepino e abobrinha (Wang, 1993), pêssego (Kluge et al., 1996), ameixa (Kluge et al., 2002), berinjela, quiabo e pimentão (Kluge et al., 1998), maçã (Smith, 1958) e em vários frutos de caroço (Ben-Aire et al., 1970; Anderson \& Penney, 1975).

Temperaturas mais baixas que $10^{\circ} \mathrm{C}$ tem sido usadas como ideais para o amadurecimento após o armazenamento refrigerado. Fernández-Trujillo et al. (2000), observaram que temperaturas de 12 a $15^{\circ} \mathrm{C}$ são inefetivas em aliviar as injúrias pelo frio em frutos submetidos a ciclos de aquecimento intermitente por 1 dias, mas $20^{\circ} \mathrm{C}$ atenua estas desordens. Observaram também que, embora a temperatura de $15^{\circ} \mathrm{C}$ tenha prevenido o risco de ataques por fungos e reduzido a perda de massa, a manutenção dos frutos nesta condição reduziu a qualidade do fruto quando o mesmo foi armazenado por mais de 1 semana devido ao amadurecimento anormal. Resfriar a fruto e depois armazenar a $15^{\circ} \mathrm{C}$ resultou numa desprezível, mas reversível inibição da atividade endo-PG, a qual está relacionada com a iniciação dos sintomas das injúrias pelo frio.

\subsection{Efeitos fisiológicos e bioquímicos dos tratamentos térmicos}

Os mecanismos de ação dos tratamentos térmicos são pouco conhecidos. Tem sido proposto que tratamentos térmicos podem promover a 
manutenção da estabilidade da membrana celular e suprimir a atividade de enzimas oxidativas, como peroxidase, polifenoloxidase e fenilalanina amonialiase, fazendo com que o fruto suporte as baixas temperaturas por mais tempo (Wang, 1993). Tem sido proposto também que esse tratamento pode provocar aumento de poliaminas (putrescina, espermidina e espermida), cuja biossíntese é estimulada em condições de estresse. Poliaminas são substâncias inibidoras de processos relacionados com a senescência, podendo proteger a membrana lipídica contra peroxidação (Wang, 1993; Artés, 1995).

As mudanças no amadurecimento do fruto durante e logo após o tratamento térmico pode ser dividida, em geral, em dois tipos. O primeiro tipo de resposta é o estresse normal da célula que conduz à modificação na sensibilidade as injúrias pelo frio, atrasando ou retardando o amadurecimento e, em alguns casos, significativas modificações na qualidade. $\mathrm{O}$ segundo tipo de resposta ocorre quando o estresse excede um limite e a habilidade da célula em se recuperar é perdida (Paull e Chen, 2000).

Frutos submetidos ao tratamento térmico apresentaram uma diminuição na percentagem de amolecimento, que pode ser devida a inibição na síntese de enzimas hidrolíticas da parede celular, como a poligalacturonase e $\alpha$ e $\beta$-galactosidase (Lurie, 1998).

$\mathrm{O}$ amolecimento é freqüentemente retardado quando o fruto é exposto a temperatura de $38-40^{\circ} \mathrm{C}$, mesmo se o tratamento é aplicado por um longo período (4 dias) antes do armazenamento (Klein e Lurie, 1990; Lurie e Nussinovitch, 1996).

A inibição do amadurecimento pelo calor pode ser explicada pelo seu efeito na produção de etileno. Em alguns produtos vegetais, como maçã e 
tomate, a exposição ao calor inibe a síntese de etileno. A inibição da síntese do etileno é anulada quando o fruto é removido do calor e, freqüentemente os níveis de etileno aumentam mais do que os frutos não tratados com calor.

As características de sabor nos frutos podem ser afetadas pelo tratamento térmico. A acidez titulável diminuiu em maçãs armazenadas de 3 a 4 dias a $38^{\circ} \mathrm{C}$, enquanto a concentração de sólidos solúveis não foi afetada pelo tratamento (Lurie, 1998).

As bruscas mudanças citológicas que seguem a exposição a altas temperaturas $\left(>45^{\circ} \mathrm{C}\right)$ têm sido descritas e incluem a coagulação do citoplasma, citólise, mudanças no núcleo e alteração na mitose.

Lurie \& Klein (1990 e 1991) observaram que o condicionamento térmico induziu a produção de proteínas de choque de calor (HSP - "heat shock protein"), que parecem estar envolvidas no processo de termo-tolerância. Embora esteja comprovada a produção de proteínas de choque de calor, esta não constitui a única resposta dos produtos submetidos aos tratamentos térmicos, portanto, existe a necessidade de pesquisas visando a exploração de outras respostas metabólicas, como forma de identificar pontos críticos que possam ser passíveis de manipulação.

O tratamento com calor pode afetar a capacidade dos sistemas biológicos em sintetizar proteínas, resultando, além do acúmulo de proteínas de choque de calor que pode induzir a termo-tolerância e a resistência às injúrias pelo frio, pode inibir a síntese de enzimas como, por exemplo, a ACC sintase, responsável pela produção de ACC (precursor imediato do etileno), e, assim, atrasar o pico de produção de etileno, e retardar a velocidade de amadurecimento dos frutos (Zhou et al., 2002). Por outro lado, temperaturas 
causadores de "chilling" podem reduzir a habilidade da enzima ACC oxidase em transformar ACC em etileno (Martínez-Romero et al., 2003).

Pesquisas mostraram que o aquecimento a $38^{\circ} \mathrm{C}$ por 4 dias, antes do armazenamento em maçãs, promoveram a manutenção da firmeza, a cor, dos SST e dos ácidos orgânicos, além disso, o estresse térmico afeta a capacidade dos sistemas biológicos em sintetizar proteínas, resultando em maior ou menor síntese das proteínas presentes e a síntese das proteínas de choque da calor.

A ação fisiológica do aquecimento intermitente consiste na ativação de enzimas de amadurecimento, como a poligalacturonase, que atua mais efetivamente na faixa de $20-25^{\circ} \mathrm{C}$. A capacidade das células em sintetizar esta enzima é progressivamente perdida quando o fruto é armazenado à baixas temperaturas, voltando ao normal com a aplicação de aquecimento durante o armazenamento.

Wang (1994) cita os seguintes prováveis efeitos do aquecimento intermitente: a) a indução de alta atividade metabólica, durante o aquecimento, a qual permite ao tecido metabolisar o excesso de intermediários ou materiais tóxicos acumulados durante a exposição às baixas temperaturas; e b) a restauração de possíveis danos ocorridos nas membranas, organelas, ou rotas metabólicas, e restabelecimento de alguma substância que foi esgotada ou impedida de ser sintetizada durante o período de exposição à baixa temperatura.

Assim, os tratamentos térmicos podem incrementar a tolerância do produto às baixas temperaturas e possibilitar o armazenamento por um maior período de tempo. Entretanto, não só o conhecimento dos efeitos dos tratamentos de controle de injúrias pelo frio é importante, mas também a 
viabilidade prática e econômica da técnica que, uma vez estabelecida, podem tornar o tratamento aplicável em nível comercial. 


\section{MATERIAL E MÉTODOS}

Foram realizados dois experimentos, sendo o primeiro na safra de $2002 \mathrm{e}$ o segundo na safra de 2003. No primeiro experimento, foi verificado o efeito dos tratamentos térmicos sobre o desenvolvimento dos sintomas de injúrias pelo frio e qualidade de pêssego, e no segundo, o efeito dos tratamentos térmicos sobre o processo respiratório e liberação de etileno dos frutos.

\subsection{Primeiro experimento}

Pêssegos da cultivar Dourado-2 foram colhidos na propriedade de um produtor da região de Itupeva - SP $\left(23^{\circ} 06^{\prime} \mathrm{S}\right.$ e $46^{\circ} 55^{\prime} \mathrm{W}$; clima tipo Cwa, denominado mesotérmico de inverno seco ou tropical de altitude http://www.itupeva.sp.gov.br/clima.htm), no estádio de maturação fisiológica (quebra da coloração verde de fundo) (Figura 1A). Os frutos foram selecionados quanto ao tamanho e ausência de defeitos físicos e fitopatológicos e submetidos aos seguintes tratamentos:

$\mathrm{T} 1=$ Frutos sem tratamento e armazenados a $0^{\circ} \mathrm{C}$ (controle);

$\mathrm{T} 2=$ Frutos expostos a $50^{\circ} \mathrm{C}$ durante uma hora e armazenados a $0^{\circ} \mathrm{C}$;

$\mathrm{T} 3=$ Frutos expostos a $50^{\circ} \mathrm{C}$ durante duas horas e armazenados a $0^{\circ} \mathrm{C}$;

$\mathrm{T} 4=$ Frutos expostos a $38^{\circ} \mathrm{C}$ durante 24 horas e armazenados a $0^{\circ} \mathrm{C}$;

$\mathrm{T} 5=$ Frutos expostos a $20^{\circ} \mathrm{C}$ durante 48 horas e armazenados a $0^{\circ} \mathrm{C}$; 
$\mathrm{T} 6=$ Frutos armazenados a $0^{\circ} \mathrm{C}$, com aquecimento a cada cinco dias a $25^{\circ} \mathrm{C}$ durante 24 horas;

$\mathrm{T} 7=$ Frutos armazenados a $0^{\circ} \mathrm{C}$, com aquecimento a cada cinco dias a $25^{\circ} \mathrm{C}$ durante 48 horas;

$\mathrm{T} 8=$ Frutos armazenados a $0^{\circ} \mathrm{C}$, com aquecimento a cada cinco dias a $15^{\circ} \mathrm{C}$ durante 24 horas;

$\mathrm{T} 9=$ Frutos armazenados a $0^{\circ} \mathrm{C}$, com aquecimento a cada cinco dias a $15^{\circ} \mathrm{C}$ durante 48 horas;

$\mathrm{T} 10=$ Frutos armazenados a $0^{\circ} \mathrm{C}$ por dez dias +48 horas a $25^{\circ} \mathrm{C}+$ nove dias a $0^{\circ} \mathrm{C}$;

$\mathrm{T} 11=$ Frutos armazenados por dez dias a $0^{\circ} \mathrm{C}+48$ horas a $15^{\circ} \mathrm{C}+$ nove dias a $0^{\circ} \mathrm{C}$;

$\mathrm{T} 12=$ Frutos armazenados por dez dias a $0^{\circ} \mathrm{C}+24$ horas a $38^{\circ} \mathrm{C}+\operatorname{dez}$ dias a $0^{\circ} \mathrm{C}$.

\subsection{Segundo experimento}

Os quatro tratamentos melhores e mais viáveis de serem utilizados pelos produtores, e mais o controle foram aplicados neste experimento. Para tanto, os frutos foram colhidos na mesma propriedade seguindo os mesmos critérios de colheita e seleção do primeiro experimento (Figura 1B).

Os seguintes tratamentos foram aplicados:

$\mathrm{T} 1=$ Frutos sem tratamento e armazenados a $0^{\circ} \mathrm{C}$ (controle);

$\mathrm{T} 2=$ Frutos expostos a $50^{\circ} \mathrm{C}$ durante duas horas e armazenados a $0^{\circ} \mathrm{C}$;

$\mathrm{T} 3=$ Frutos expostos a $20^{\circ} \mathrm{C}$ durante 48 horas e armazenados a $0^{\circ} \mathrm{C}$;

$\mathrm{T} 4=$ Frutos armazenados a $0^{\circ} \mathrm{C}$, com aquecimento a cada cinco dias a $25^{\circ} \mathrm{C}$ durante 24 horas;

$\mathrm{T} 5=$ Frutos armazenados a $0^{\circ} \mathrm{C}$ por dez dias +48 horas a $25^{\circ} \mathrm{C}+$ nove dias a $0^{\circ} \mathrm{C}$. 

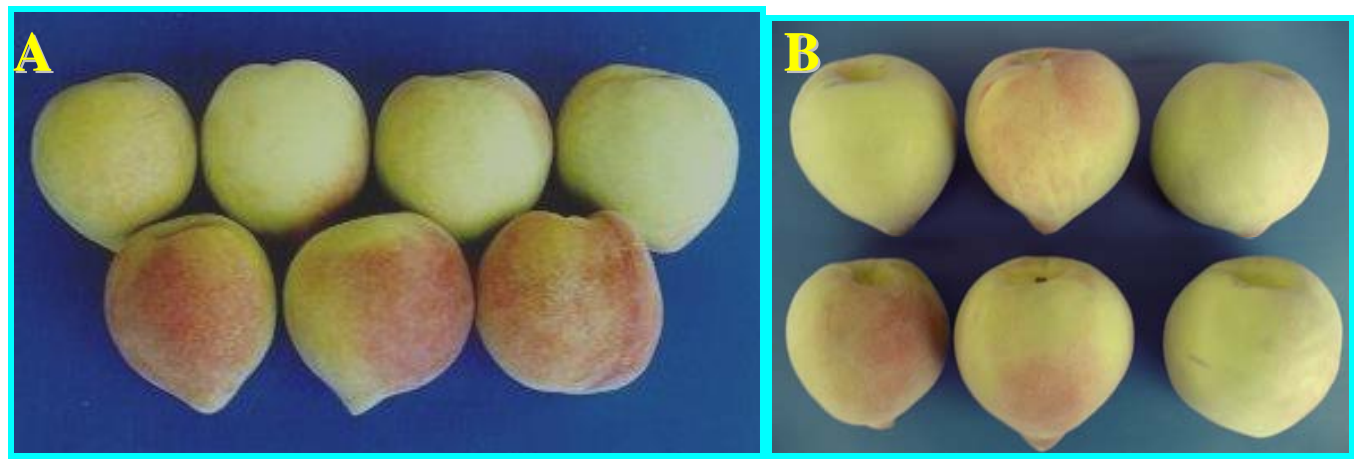

Figura 1 - Aspecto geral de pêssegos 'Dourado-2' recém colhidos, antes de serem submetidos aos tratamentos. $\mathrm{A}=$ Experimento 1 e $\mathrm{B}=$ Experimento 2

Para a aplicação dos tratamentos térmicos foram utilizadas câmaras tipo B.O.D. reguladas para as temperaturas propostas.

\subsection{Armazenamento dos frutos}

Os frutos foram armazenados em câmaras frigoríficas do Departamento de Produção Vegetal da Escola Superior de Agricultura “Luiz de Queiroz" da Universidade de São Paulo, USP/ESALQ, em Piracicaba, SP (Figura 2A).

Em ambos os experimentos, o período total de armazenamento foi de 30 dias. Após o período de refrigeração, os frutos foram submetidos a uma comercialização simulada de 3 dias a $25^{\circ} \mathrm{C}$, sendo avaliados após este período.

\subsection{Determinações}

As seguintes variáveis foram analisadas:

a) Coloração da casca - determinada utilizando-se a metodologia de McGuirre (1992). Através do equipamento Minolta Chroma Meter CR-300 foram determinados os valores de ângulo de cor e croma, efetuando-se duas leituras 
por fruto, em dois pontos eqüidistantes na zona equatorial do fruto, avaliando-se a cor de fundo.

b) Firmeza de polpa - determinada utilizando-se um penetrômetro manual com ponteira plana de $8 \mathrm{~mm}$ de diâmetro. Foram efetuadas duas leituras por fruto, em lados opostos da região equatorial os mesmos, após a remoção de uma pequena e superficial porção da casca. Os resultados foram expressos em Newtons.

c) Teor de sólidos solúveis - determinado em refratômetro digital, com correção automática de temperatura para $20^{\circ} \mathrm{C}$. Os resultados foram expressos em ${ }^{\circ}$ Brix.

d) Acidez total titulável - determinada pela titulação potenciométrica com $\mathrm{NaOH} 0,1 \mathrm{~N}$ até $\mathrm{pH} 8,10$ de $10 \mathrm{~g}$ da amostra triturada em $90 \mathrm{ml}$ de água destilada. Os resultados foram expressos em \% de acidez. 


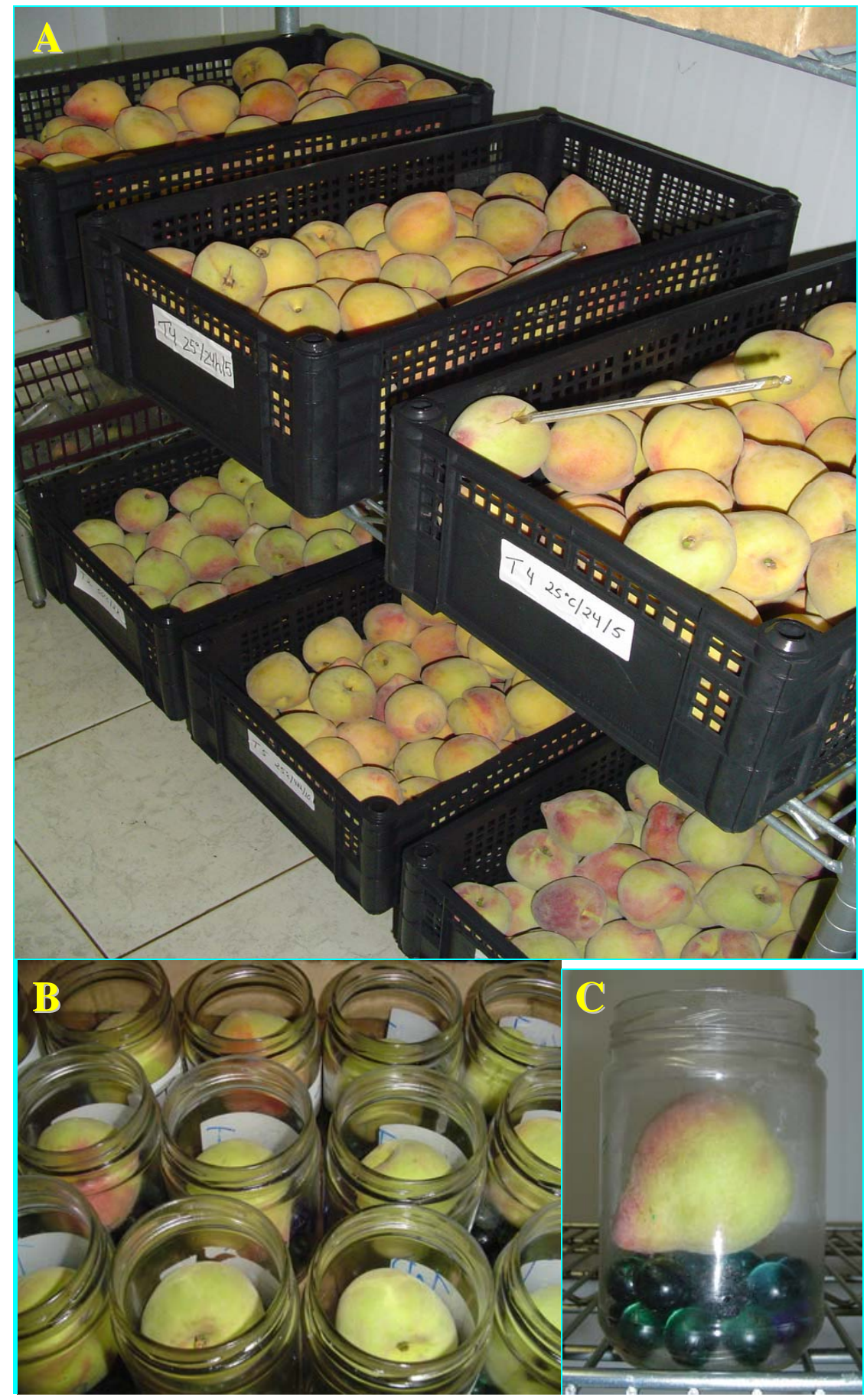

Figura 2 - (A) Visão geral das caixas dentro da câmara fria; (B) Frascos de vidro utilizados para medir a respiração e a produção de etileno; (C) Frasco em detalhe com o fruto e as bolas de vidro 
e) Teor de vitamina C - determinado de acordo com metodologia de Carvalho et al. (1990), a qual se baseia na redução do indicador 2,6-diclorofenol indolfenol-sódio (DCFI) pelo ácido ascórbico. Foram pesadas $10 \mathrm{~g}$ da amostra e colocada em erlenmeyer contendo $50 \mathrm{ml}$ de solução de ácido oxálico. A titulação foi efetuada com DCFI até atingir a coloração rosada persistente por 15 segundos. Os resultados foram expressos em mg de ácido ascórbico por $100 \mathrm{~g}$ de polpa.

Estas variáveis foram analisadas logo após a colheita em 4 repetições de 5 frutos, no primeiro experimento, e em 5 repetições de 5 frutos no segundo, e após a saída dos frutos do armazenamento seguidos de mais 3 dias de comercialização simulada.

No primeiro experimento foi determinada também a perda de massa e realizada a análise sensorial. A perda de massa foi determinada pela diferença, em \%, entre a massa inicial da repetição e a massa verificada após tratamentos e armazenamento, seguidos de 3 dias de comercialização simulada. A massa foi determinada utilizando-se balança com precisão de 1g. Para a análise deste parâmetro foram separadas 4 bandejas com 6 frutos cada.

As características sensoriais dos frutos foram determinadas após o período total de armazenamento (+3 dias de comercialização simulada). Cada tratamento foi representado por uma amostra de 4 frutos (um de cada repetição). As avaliações foram realizadas por 17 provadores, sendo eles técnicos de laboratórios e estagiários do Departamento. Para a composição da equipe foram selecionadas pessoas não fumantes, com habilidade para detectar variações nos 
atributos de qualidade de pêssegos e com disponibilidade de horário nas datas previamente agendadas.

Foi utilizada uma escala de 1 a 9, onde 9 é o extremo negativo, ou seja, desgostei extremamente, e 1 o extremo positivo, ou seja, gostei extremamente, (Figura 3) onde aparência, sabor, odor e textura foram analisados.

As injúrias pelo frio foram determinadas por metodologia adaptada de Ju et al. (2000), baseada na aparência e quantidade de suco extraído a partir da trituração do fruto em centrífuga doméstica. Os frutos foram divididos em cinco categorias: 1 = fruto firme, com aparência de seco e nenhuma extração de suco; 2 = fruto firme, com aparência de seco e alguma extração de suco; 3 = fruto mole, com aparência de seco e nenhuma extração de suco; 4 = fruto mole, com aparência de seco e alguma extração de suco e 5 = fruto mole, com aparência de úmido e com muita extração de suco.

A incidência de podridão foi medida através da observação da área da superfície afetada, atribuindo às mesmas notas de acordo com as seguintes categorias: $1=0 \%, 2=<5 \%, 3=5-25 \%, 4=25-50 \%$ e $5=>50 \%$ da área da superfície afetada.

No segundo experimento a taxa respiratória e a produção de etileno foram medidas nos frutos. Para isso, foram utilizados frascos de vidro de aproximadamente $600 \mathrm{~mL}$, fechados com tampa de metal provida de septo de silicone, os quais foram fechados diariamente por 1 hora (Figura 2B e C). Cada tratamento foi representado por 6 frascos com 1 fruto por frasco, o qual também continha bolas de vidro a fim de se diminuir o espaço livre dentro do mesmo. Após permanecerem por 1 hora fechados, coletou-se uma amostra de $1 \mathrm{~mL}$ de gás do interior de cada frasco, utilizando-se seringa modelo Gastight, marca 
Hamilton de 2,5mL. As amostras foram injetadas no cromatógrafo a gás (modelo GC Trace 2000, marca Thermofinnigan), com detector de ionização de chama (FID), utilizando-se uma coluna "Propak N". O gás de arraste utilizado foi o hidrogênio, a um fluxo de $30 \mathrm{ml} /$ minuto. As temperaturas mantidas no aparelho foram de $80^{\circ} \mathrm{C}$ para a coluna, $100^{\circ} \mathrm{C}$ no injetor, $250^{\circ} \mathrm{C}$ no detector e $350^{\circ} \mathrm{C}$ no metanador. Os resultados da respiração foram expresso em $\mathrm{mL}$ de $\mathrm{CO}_{2} \mathrm{~kg}^{-1} \mathrm{~h}^{-1} \mathrm{e}$ os de etileno em $\mu \mathrm{L}$ de etileno $\mathrm{kg}^{-1} \mathrm{~h}^{-1}$.

\subsection{Delineamento experimental e Análise estatística}

O delineamento experimental foi inteiramente ao acaso, com 12 tratamentos e 4 repetições de 5 frutos, no primeiro experimento, e com 5 tratamentos e 5 repetições de 10 frutos no segundo experimento. Para as análises de etileno e respiração foram utilizados 6 repetições de 1 fruto.

Os dados coletados foram submetidos à análise de variância (teste F) e comparação de médias pelo teste de Tukey, em nível de 5\% de probabilidade, utilizando-se o pacote estatístico SAS. 


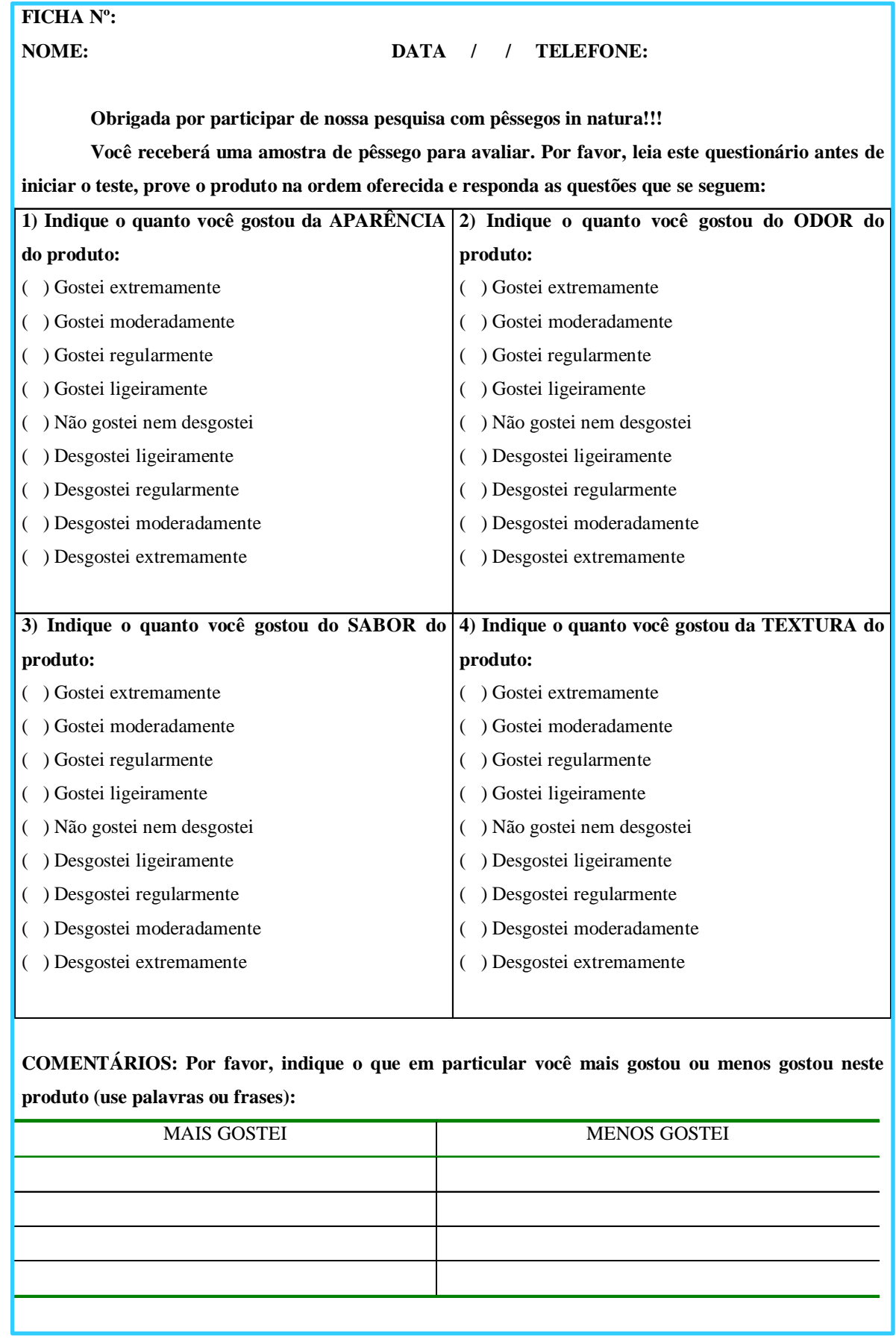

Figura 3 - Ficha utilizada na análise sensorial 


\section{RESULTADOS E DISCUSSÃO}

\subsection{Primeiro experimento}

Os frutos que foram armazenados a $0^{\circ} \mathrm{C}$, com aquecimento a cada cinco dias a $25^{\circ} \mathrm{C}$ durante 48 horas (T7), se apresentavam em adiantado estádio de maturação e senescência, com presença de podridões após o período de armazenamento (Figura 4A). Após 3 dias de comercialização simulada, todos os frutos deste tratamento estavam completamente deteriorados, caracterizando o tratamento como ineficiente na frigoconservação de pêssegos 'Dourado-2' (Figura 4B). Os frutos dos demais tratamentos, apesar das diferenças entre aspectos visuais como coloração e incidência de podridões, se apresentaram aptos ao consumo.

Após o período de comercialização simulada, os frutos de todos os tratamentos apresentaram uma redução marcante na firmeza. Os frutos apresentavam, no momento da colheita, firmeza de 53,78N e atingiram valores entre 2,82 a 4,12N após o armazenamento e comercialização simulada (Tabela 1). Observa-se que os tratamentos não provocaram diferenças na firmeza quando comparados ao controle. Uma explicação para esse comportamento seria que as injúrias pelo frio, no tratamento controle, conduziriam a um estresse que levaria a perda da firmeza pela mudança na atividade normal das enzimas poligalacturonase e pectinametilesterase. Nos tratamentos com 
aquecimento, o efeito das altas temperaturas produziria este efeito, pelo aumento na taxa de produção de etileno. Choi e Lee (2001) encontraram, em pêssegos 'Mibaekto', esse mesmo comportamento pouco efetivo dos tratamentos em relação à firmeza. Fernández-Trujillo e Artés (1997) encontraram uma diminuição na firmeza proporcional ao aumento da temperatura de aquecimento para a cultivar Paraguayo. Girardi ${ }^{1}$, estudando o efeito do aquecimento intermitente na cultivar Chiripá, verificou que, ao retirar os frutos da condição refrigerada no 15 o dia e mantê-los 24 horas a $20^{\circ} \mathrm{C}$ depois recolocá-los na condição refrigerada e no 35o dia submetê-los a 5 dias de comercialização simulada, a firmeza foi reduzida drasticamente.

Obenland et al. (2003) observaram que, após 6 semanas de armazenamento a $5^{\circ} \mathrm{C}$, a firmeza de pêssegos 'Autumm Red' diminuiu gradualmente até a $4^{\mathrm{a}}$ semana e que nas duas últimas semanas a diminuição foi drástica. Verificaram também que a mudança na firmeza foi acompanhada por uma mudança na coloração (de verde para amarelo avermelhado) à medida que o fruto amadurecia.

Zhou et al. (2002) observaram que a firmeza de pêssegos 'Hujin', que inicialmente era de $47,97 \mathrm{~N}$, diminuiu para $4,75 \mathrm{~N}$ após 6 dias de armazenamento à temperatura ambiente, enquanto que a firmeza dos frutos armazenados a $2,3^{\circ} \mathrm{C}$ por 6 dias foi de $40,39 \mathrm{~N}$. Por outro lado, os mesmos autores observaram que a firmeza de pêssegos 'Baihua' tratados com ar quente a $37^{\circ} \mathrm{C}$ por 16 ou 24 horas e a $43^{\circ} \mathrm{C}$ por 8 horas foi maior que o controle.

\footnotetext{
${ }^{1}$ GIRARDI, C.L. Comunicação pessoal, 2003.
} 


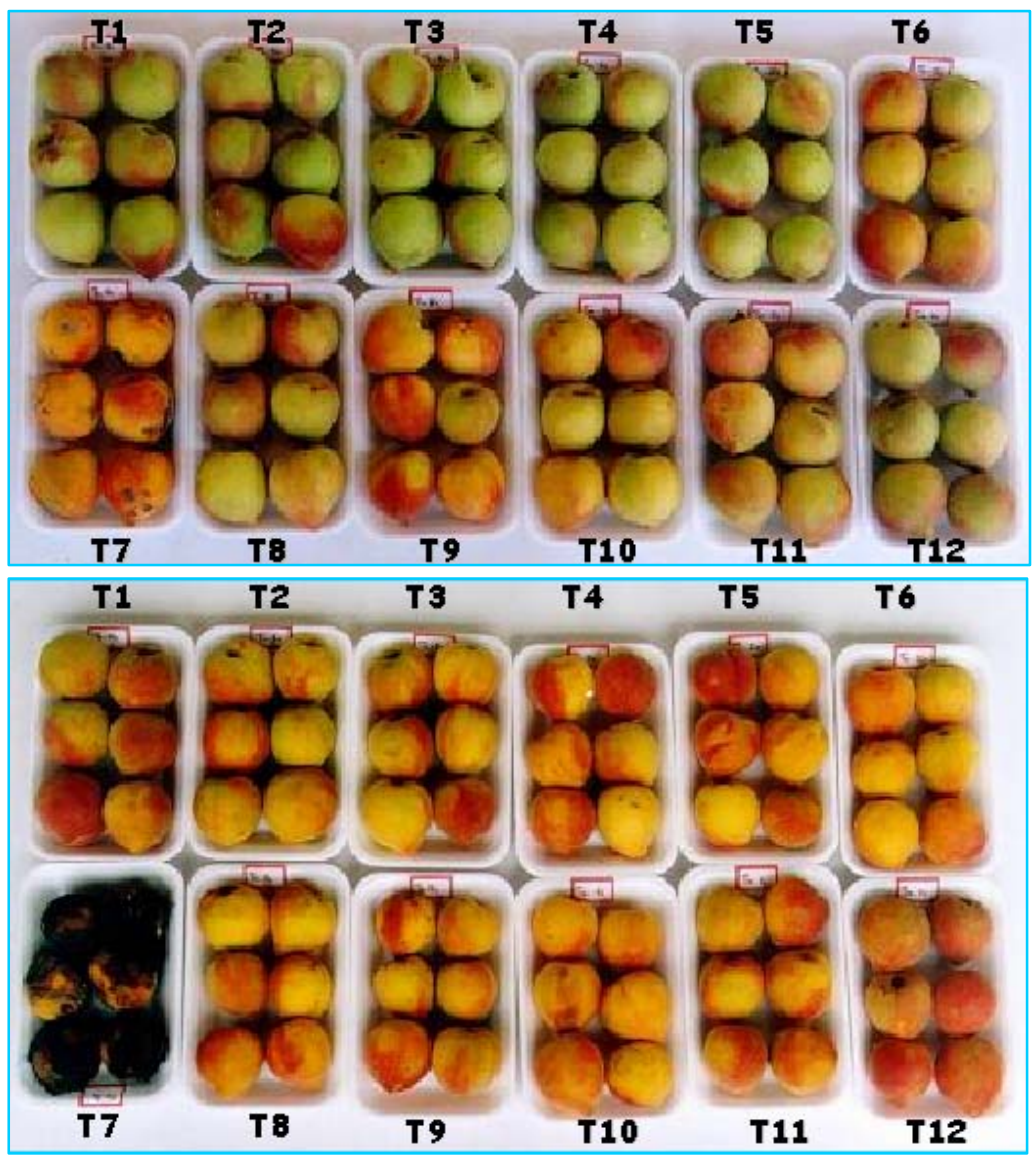

Figura 4 - Aspecto geral de pêssegos 'Dourado-2' submetidos a diferentes tratamentos e armazenados a $0^{\circ} \mathrm{C}$ e 90-95\% UR durante 30 dias (A) e após 3 dias de comercialização simulada a $25^{\circ} \mathrm{C}(\mathrm{B}) . \mathrm{T} 1=$ Frutos sem tratamento e armazenados a $0^{\circ} \mathrm{C}$ (controle); $\mathrm{T} 2=$ Frutos expostos a $50^{\circ} \mathrm{C}$ durante uma hora e armazenados a $0^{\circ} \mathrm{C} ; \mathrm{T} 3=$ Frutos expostos a $50^{\circ} \mathrm{C}$ durante duas horas e armazenados a $0^{\circ} \mathrm{C} ; \mathrm{T} 4=$ Frutos expostos a $38^{\circ} \mathrm{C}$ durante 24 horas e armazenados a $0^{\circ} \mathrm{C} ; \mathrm{T} 5=$ Frutos expostos a $20^{\circ} \mathrm{C}$ durante 48 horas e armazenados a $0^{\circ} \mathrm{C}$; $\mathrm{T} 6=$ Frutos armazenados a $0^{\circ} \mathrm{C}$, com aquecimento a cada cinco dias a $25^{\circ} \mathrm{C}$ durante 24 horas; $\mathrm{T} 7=$ Frutos armazenados a $0^{\circ} \mathrm{C}$, com aquecimento a cada cinco dias a $25^{\circ} \mathrm{C}$ durante 48 horas; $\mathrm{T} 8=$ Frutos armazenados a $0^{\circ} \mathrm{C}$, com aquecimento a cada cinco dias a $15^{\circ} \mathrm{C}$ durante 24 horas; $\mathrm{T} 9=$ Frutos armazenados a $0^{\circ} \mathrm{C}$, com aquecimento a cada cinco dias a $15^{\circ} \mathrm{C}$ durante 48 horas; $\mathrm{T} 10=$ Frutos armazenados a $0^{\circ} \mathrm{C}$ por dez dias +48 horas a $25^{\circ} \mathrm{C}+$ nove dias a $0^{\circ} \mathrm{C} ; \mathrm{T} 11=$ Frutos armazenados por dez dias a $0^{\circ} \mathrm{C}+48$ horas a $15^{\circ} \mathrm{C}+$ nove dias a $0^{\circ} \mathrm{C} ; \mathrm{T} 12=$ Frutos armazenados por dez dias a $0^{\circ} \mathrm{C}+24$ horas a $38^{\circ} \mathrm{C}+$ dez dias a $0^{\circ} \mathrm{C}$. 
Tabela 1. Perda de massa, firmeza de polpa, incidência de podridão e de lanosidade em pêssegos 'Dourado-2' armazenados durante 30 dias a $0^{\circ} \mathrm{C}$ e $90-95 \%$ UR seguido de 3 dias de comercialização simulada a $25^{\circ} \mathrm{C}^{1}$

\begin{tabular}{lccll}
\hline Tratamento & $\begin{array}{c}\text { Perda de } \\
\text { massa }(\%)\end{array}$ & $\begin{array}{c}\text { Firmeza } \\
(\mathrm{N})^{2}\end{array}$ & $\begin{array}{c}\text { Incidência } \\
\text { de podridão }\end{array}$ & $\begin{array}{c}\text { Incidência de } \\
\text { lanosidade }^{4}\end{array}$ \\
\hline Controle & $15,55 \mathrm{~b}$ & $3,60 \mathrm{abc}$ & $1,95 \mathrm{bcd}$ & $3,55 \mathrm{bc}$ \\
Condicionamento Térmico & & & & \\
$50^{\circ} \mathrm{C} / 1 \mathrm{~h}$ & $16,65 \mathrm{~b}$ & $3,49 \mathrm{abc}$ & $1,30 \mathrm{~cd}$ & $2,70 \mathrm{~d}$ \\
$50^{\circ} \mathrm{C} / 2 \mathrm{~h}$ & $17,22 \mathrm{~b}$ & $3,66 \mathrm{abc}$ & $1,55 \mathrm{~cd}$ & $2,95 \mathrm{~cd}$ \\
$38^{\circ} \mathrm{C} / 24 \mathrm{~h}$ & $15,06 \mathrm{~b}$ & $3,80 \mathrm{ab}$ & $1,85 \mathrm{bcd}$ & $4,30 \mathrm{ab}$ \\
$20^{\circ} \mathrm{C} / 48 \mathrm{~h}$ & $18,73 \mathrm{ab}$ & $2,82 \mathrm{c}$ & $1,15 \mathrm{~d}$ & $5,00 \mathrm{a}$ \\
Aquecimento Intermitente & & & & \\
$25^{\circ} \mathrm{C} / 24 \mathrm{~h}$, a cada 5 dias & $16,53 \mathrm{~b}$ & $3,72 \mathrm{abc}$ & $2,10 \mathrm{bc}$ & $4,95 \mathrm{a}$ \\
$25^{\circ} \mathrm{C} / 48 \mathrm{~h}$, a cada 5 dias & - & - & $5,00 \mathrm{a}$ & - \\
$15^{\circ} \mathrm{C} / 24 \mathrm{~h}$, a cada 5 dias & $18,45 \mathrm{ab}$ & $4,12 \mathrm{a}$ & $1,75 \mathrm{bcd}$ & $4,85 \mathrm{a}$ \\
$15^{\circ} \mathrm{C} / 48 \mathrm{~h}$, a cada 5 dias & $21,56 \mathrm{a}$ & $3,51 \mathrm{abc}$ & $2,15 \mathrm{bc}$ & $5,00 \mathrm{a}$ \\
$25^{\circ} \mathrm{C} / 48 \mathrm{~h}$, a cada 10 dias & $16,25 \mathrm{~b}$ & $3,56 \mathrm{abc}$ & $2,55 \mathrm{~b}$ & $4,95 \mathrm{a}$ \\
$15^{\circ} \mathrm{C} / 48 \mathrm{~h}$, a cada 10 dias & $16,17 \mathrm{~b}$ & $3,13 \mathrm{bc}$ & $1,85 \mathrm{bcd}$ & $4,95 \mathrm{a}$ \\
$38^{\circ} \mathrm{C} / 24 \mathrm{~h}$, a cada 10 dias & $17,38 \mathrm{~b}$ & $3,65 \mathrm{abc}$ & $0,75 \mathrm{bcd}$ & $4,55 \mathrm{a}$ \\
\hline
\end{tabular}

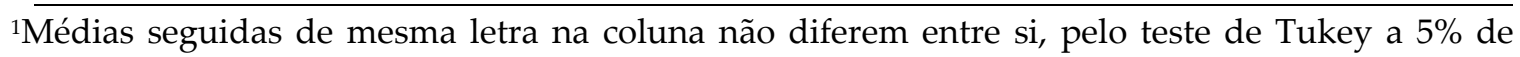
probabilidade.

2 Firmeza Inicial $=53,78 \mathrm{~N}$

${ }^{3} 1=0 \%, 2<5 \%, 3=5-25 \%, 4=25-50 \%$ e $5=>50 \%$ da área da superfície afetada;

${ }^{4} 1$ = fruto firme, com aparência de seco e nenhuma extração de suco; 2 = fruto firme, com aparência de seco e alguma extração de suco; 3 = fruto mole, com aparência de seco e nenhuma extração de suco; 4 = fruto mole, com aparência de seco e alguma extração de suco e 5 = fruto mole, com aparência de úmido e com muita extração de suco. 
Quanto à incidência de podridões, observou-se, de maneira geral, a presença de 0 a $5 \%$ da área afetada com podridão, o que pode ser considerada baixa. Entretanto, os frutos armazenados a $0^{\circ} \mathrm{C}$, com aquecimento a cada cinco dias a $25^{\circ} \mathrm{C}$ durante 48 horas, apresentaram $100 \%$ de podridão (Tabela 1). A freqüência e o tempo de aquecimento provavelmente foram os responsáveis por este resultado. Os principais fungos encontrados foram Cladosporium sp., Rhizopus sp., e a bactéria causadora da Ferrugem (Figura 5).

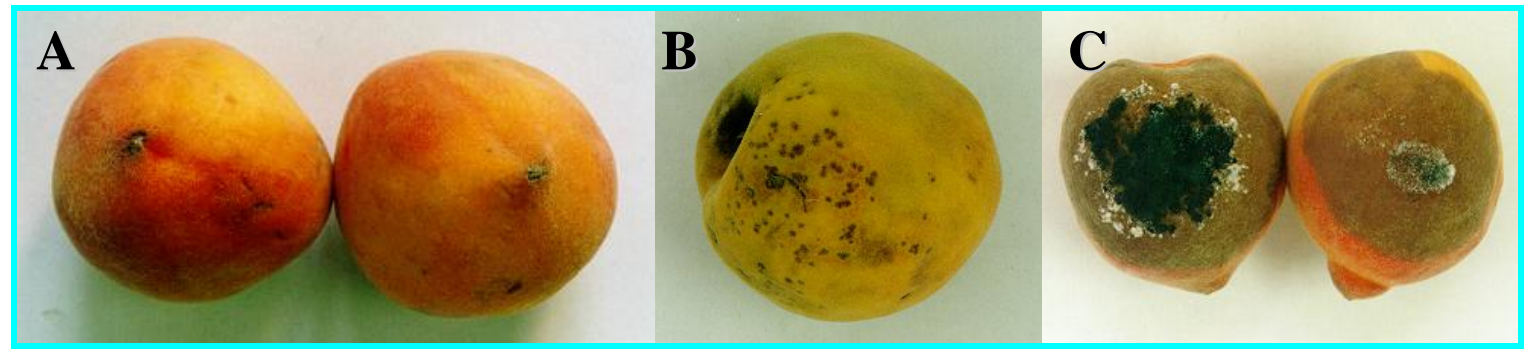

Figura 5 - Aspecto de algumas doenças encontradas após o período de armazenamento refrigerado de pêssegos 'Dourado 2' seguido de 3 dias de comercialização simulada: (A) Ferrugem, (B) Cladosporium e (C) Rhizopus

Para a cultivar Chiripá, a aplicação do aquecimento intermitente promoveu uma significativa perda da firmeza da polpa e aumentou a incidência de podridões, apesar de reduzir a incidência de lanosidade (Girardi¹).

Em relação à lanosidade, observou-se que os frutos do controle e os aquecidos a $50^{\circ} \mathrm{C}$ por 1 ou 2 horas, apresentavam-se moles, porém com aparência seca e nenhuma ou pouca extração de suco, sintomas característicos de distúrbios pelo frio (Figura 6). $\mathrm{O}$ aquecimento a $50^{\circ} \mathrm{C}$ provavelmente causou um maior desbalanço na atividade da poligalacturonase e pectinametilesterase, 
o que pode ter intensificado o problema. Os demais tratamentos resultaram em frutos com baixo nível de lanosidade (Tabela 1).

Nos frutos submetidos ao aquecimento intermitente, os resultados foram satisfatórios no que se refere ao controle da lanosidade. Estes resultados estão de acordo com o encontrado para outras cultivares, como Mibaekto (Choi e Lee, 2001), Okuba (Li-Ping e Tao, 1998) e Chiripá (Girardi¹).

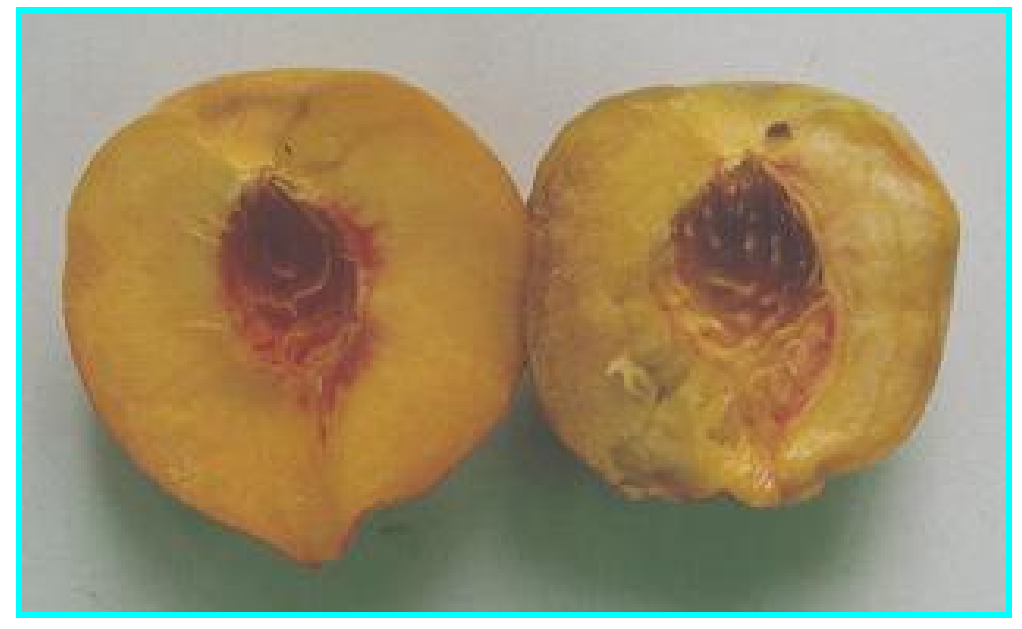

Figura 6 - Aspecto de fruto com lanosidade após o período de armazenamento refrigerado seguido de 3 dias de comercialização simulada

Apesar da subjetividade do método, a quantidade de suco extraível se correlaciona bem com o desenvolvimento e o grau de lanosidade (Luchsinger e Walsh, 1998).

No presente experimento, embora o aquecimento intermitente tenha reduzido a incidência de lanosidade, pôde-se verificar uma desvantagem neste tratamento que é a perda maior na firmeza da polpa dos frutos. Kluge et al. (1996) também verificaram fato semelhante em pêssego 'BR-6' que sofreram aquecimento intermitente. Entretanto, a BR-6 é uma cultivar para indústria, e a 
perda de firmeza do fruto prejudica o processamento, enquanto que, para a Dourado-2, por ser uma cultivar de mesa, não haveria maiores problemas quanto ao consumo do fruto.

Observou-se, de maneira geral, uma elevada perda de massa nos tratamentos. A perda de massa é provocada, principalmente pela transpiração, e é tanto maior quanto maior a temperatura e o período de exposição dos frutos a ela. A elevada perda de massa era esperada, considerando-se que os tratamentos térmicos elevam o déficit de pressão de vapor (DPV) entre os tecidos internos do fruto e o ambiente, favorecendo um aumento na transpiração (Handenburg et al., 1986).

Peano et al. (2001), estudando a cultivar Elegant Lady, observaram uma perda de massa muito acentuada nas primeiras 12 horas após a retirada do armazenamento refrigerado por dois dias, diminuindo gradualmente após este período. Observaram também uma perda de firmeza paralela a perda de massa. De fato, a perda de água pela transpiração favorece uma redução na turgescência do fruto e contribui para uma queda na firmeza da polpa. Fernández-Trujillo et al. (2000) observaram, para a cultivar Miraflores, uma maior perda de massa a $20^{\circ} \mathrm{C}$ do que a $15^{\circ} \mathrm{C}$, fato relacionado com um estresse inicial causado pelo aquecimento, aumentando também a respiração. Akbudak e Eris (2004), estudando o efeito do aquecimento intermitente em pêssegos 'Flavorcrest' e 'Red Top', observaram um significante aumento na perda de massa durante o armazenamento, que continuou durante o período de comercialização simulada.

Os valores de vitamina $C$ não diferiram significativamente entre os tratamentos, variando de 0,00113 a 0,00201 de ácido ascórbico/100 g de polpa, 
(Tabela 2), mas diminuíram em mais da metade, em alguns casos, comparados à caracterização inicial. Este fato era esperado já que existe uma relação inversa entre senescência e conteúdo de ácido ascórbico. O ácido ascórbico é um antioxidante natural que vai sendo consumido à medida que a senescência se desenvolve como forma de reparar danos oxidativos nas células. Este decréscimo depende, em grande parte, da duração e da temperatura de armazenamento (Thé, 2001).

A Dourado-2 é uma cultivar com baixo teor de vitamina C, considerando os valores observados no presente experimento. Gil et al. (2002) verificaram uma variação de 3,6 a 12,6 mg de ácido ascórbico/100g de polpa fresca, em cultivares de polpa branca e amarela da Califórnia.

De acordo com Gonçalves (1998), o conteúdo de vitamina C natural da muitos frutos depende de vários fatores, incluindo cultivares, estádio de maturação, condições de cultivo e época de colheita.

Nos frutos submetidos ao armazenamento contínuo ou tratados termicamente, a acidez diminuiu após o período de armazenamento, mas não apresentou diferenças, mostrando que, para esta cultivar, esta variável não se modifica drasticamente durante o amadurecimento (Tabelas 2). Para as cultivares Chiripá (Girardi1) e Flavorcrest e Red Top (Akbudak e Eris, 2004), a acidez diminuiu em função dos tratamentos. Para a maioria dos frutos, a redução na acidez é um evento normal e a velocidade com que ocorre é diretamente proporcional à temperatura que afeta a produção de etileno e a atividade respiratória. Os ácidos predominantes encontrados nos frutos são o málico, o cítrico, o tartárico, o acético, o oxálico, dentre outros (Wills et al., 1998; Kluge et al., 1997). No pêssego, o ácido mais importante é o málico. 
Para uma mesma cultivar, a acidez é influenciada por condições climáticas, estádio de maturação e localização do fruto na planta, sendo também variável de ano para ano (Girardi1 $)$

Os maiores valores de sólidos solúveis totais (SST) foram obtidos nos frutos armazenados continuamente a $0^{\circ} \mathrm{C}$ e nos frutos expostos a $50^{\circ} \mathrm{C}$ durante uma hora antes do armazenamento (Tabela 2). Os menores valores de SST foram encontrados nos frutos armazenados a $0^{\circ} \mathrm{C}$ com aquecimento a cada cinco dias a $25^{\circ} \mathrm{C}$ durante 24 horas, e nos frutos armazenados por dez dias a $0^{\circ} \mathrm{C}+24$ horas a $38^{\circ} \mathrm{C}+$ dez dias a $0^{\circ} \mathrm{C}$, não havendo diferenças significativas entre os demais tratamentos. Uma possível relação entre a perda de peso e a concentração de sólidos solúveis não foi verificada. Observou-se uma tendência à diminuição de SST nos tratamentos submetidos ao aquecimento, seja na forma de condicionamento térmico, ou na forma de aquecimento intermitente, embora este efeito tenha sido pouco significativo.

O aquecimento intermitente em pêssegos 'Chiripá' (Girardi'1), 'Hujin' (Zhou et al., 2002), 'Elegant Lady' (Peano et al., 2001) e 'Okuba' (Li-Ping e Tao, 1998) também não provocou efeito no teor de SST.

Após resfriamento até $1^{\circ} \mathrm{C}$, e posterior manutenção por 10 dias a 15 e $20^{\circ} \mathrm{C}$, pêssegos 'Miraflores' não apresentaram diferenças significativas quanto ao teor de SST, mas a acidez, o "ratio" e a firmeza diferiram significativamente dos valores obtidos logo após a colheita, assim como acontece com outras cultivares de pêssego (Fernández-Trujillo et al., 2000).

O teor de sólidos solúveis dá um indicativo da quantidade de açúcares existentes no fruto, considerando que outros compostos, embora em reduzidas proporções, também façam parte, como, por exemplo, ácidos, vitaminas, 
aminoácidos e algumas pectinas. O teor de SST dá uma idéia da doçura do fruto durante a maturação e é um importante atributo na determinação do seu sabor (Kluge et al., 1997).

Com o amadurecimento, ocorre a síntese dos sólidos solúveis, ou a degradação de polissacarídeos, fazendo com que seu valor aumente até certo ponto, a partir do qual começam a ser utilizados na manutenção da atividade metabólica do fruto (Bron, 2002), enquanto que o $\mathrm{pH}$ e o teor de acidez diminuem (Holland, 1993).

Tendo-se os valores dos sólidos solúveis totais e da acidez total titulável, pode-se obter a relação entre estes dois parâmetros. Esta relação é utilizada em muitos frutos para se avaliar o amadurecimento, já que esse quociente determina o "flavor" do fruto. Entretanto, sendo alguns constituintes voláteis, essa relação é mais indicativa do sabor, pois se utiliza a acidez titulável e não a acidez total (Holland, 1993). 
Tabela 2. Teor de vitamina C, sólidos solúveis totais (SST), acidez total titulável (ATT), e relação SST/ATT em pêssegos 'Dourado-2' armazenados durante 30 dias a $0^{\circ} \mathrm{C}$ e 90-95\% UR seguido de 3 dias de comercialização simulada a $25^{\circ} \mathrm{C}^{1}$

\begin{tabular}{lcccc}
\hline Tratamento & $\begin{array}{c}\text { Vit C (mg ácido } \\
\text { ascórbico/100g) }\end{array}$ & $\begin{array}{c}\text { SST } \\
\left({ }^{0} \text { Brix }\right)^{2}\end{array}$ & $\begin{array}{c}\text { ATT } \\
(\%)^{2}\end{array}$ & SST/ATT 2 \\
\hline Controle & $0,00187 \mathrm{a}$ & $11,37 \mathrm{a}$ & $0,374 \mathrm{ab}$ & $30,93 \mathrm{ab}$
\end{tabular}

Condicionamento Térmico

$\begin{array}{lcccc}50^{\circ} \mathrm{C} / 1 \mathrm{~h} & 0,00117 \mathrm{a} & 11,45 \mathrm{a} & 0,370 \mathrm{ab} & 29,05 \mathrm{ab} \\ 50^{\circ} \mathrm{C} / 2 \mathrm{~h} & 0,00113 \mathrm{a} & 10,77 \mathrm{ab} & 0,390 \mathrm{a} & 27,60 \mathrm{~b} \\ 38^{\circ} \mathrm{C} / 24 \mathrm{~h} & 0,00165 \mathrm{a} & 10,42 \mathrm{ab} & 0,364 \mathrm{ab} & 28,78 \mathrm{~b} \\ 20^{\circ} \mathrm{C} / 48 \mathrm{~h} & 0,00160 \mathrm{a} & 10,90 \mathrm{ab} & 0,356 \mathrm{abc} & 31,79 \mathrm{ab}\end{array}$

Aquecimento Intermitente

$25^{\circ} \mathrm{C} / 24 \mathrm{~h}$, a cada 5 dias

0,00187a

$9,90 \mathrm{~b}$

$0,286 b c$

$34,73 \mathrm{ab}$

$25^{\circ} \mathrm{C} / 48 \mathrm{~h}$, a cada 5 dias

$15^{\circ} \mathrm{C} / 24 \mathrm{~h}$, a cada 5 dias

0,00183a

$10,67 \mathrm{ab}$

$0,321 \mathrm{abc}$

$33,64 a b$

$15^{\circ} \mathrm{C} / 48 \mathrm{~h}$, a cada 5 dias

0,00181a

$11,22 \mathrm{ab}$

$0,325 \mathrm{ab}$

$34,58 \mathrm{ab}$

$25^{\circ} \mathrm{C} / 48 \mathrm{~h}$, a cada 10 dias

0,00201a

$10,25 \mathrm{ab}$

$0,262 \mathrm{c}$

$39,17 a$

$15^{\circ} \mathrm{C} / 48 \mathrm{~h}$, a cada 10 dias

$0,00115 \mathrm{a}$

$10,87 \mathrm{ab}$

$0,290 \mathrm{bc}$

$37,65 \mathrm{ab}$

$38^{\circ} \mathrm{C} / 24 \mathrm{~h}$, a cada 10 dias

0,00189a

$9,95 b$

$0,309 \mathrm{abc}$

$32,51 \mathrm{ab}$

C.V. (\%)

27,17

5,09

13,94

12,89

${ }^{1}$ Médias seguidas de mesma letra na coluna não diferem entre si, pelo teste de Tukey a 5\% de probabilidade.

2 Valores Iniciais: Vit C $=0,00267 \mathrm{mg}$ de ácido ascórbico/100g; SST $=10,22^{\circ}$ Brix; ATT $=0,411 \%$; SST $/ \mathrm{ATT}=24,87$. 
A mudança que ocorre na cor da epiderme do pêssego é um dos principais atributos que o consumidor utiliza para avaliar a qualidade do fruto.

Houve uma diminuição do ângulo de cor $(\mathrm{o} h)$, sendo que os frutos passaram da cor verde-amarelada para a coloração amarelo-avermelhada (Tabela 3). Ângulo de cor mais próximo a $180^{\circ}$ significa fruto mais verde, enquanto que mais próximo a $0^{\circ}$ mais vermelho é o fruto.

Os menores valores do ângulo de cor foram obtidos nos frutos armazenados por dez dias a $0^{\circ} \mathrm{C}+24$ horas a $38^{\circ} \mathrm{C}+$ dez dias a $0^{\circ} \mathrm{C}$ e nos frutos expostos a $38^{\circ} \mathrm{C}$ durante 24 horas e armazenados a $0^{\circ} \mathrm{C}$, o que significa que os frutos estavam significativamente mais vermelhos que os demais, ou seja, mais maduros. Os maiores valores foram obtidos nos frutos expostos a $20^{\circ} \mathrm{C}$ durante 48 horas e armazenados a $0^{\circ} \mathrm{C}$ e nos frutos controle, sendo, portanto, estes frutos, mais verdes que os demais.

Peano et al. (2001) verificaram que a cultivar Elegant Lady apresentou uma elevada perda de brilho e um acentuado escurecimento da cor após armazenamento refrigerado seguido de comercialização simulada. FernándezTrujillo et al. (2000) observaram que, em pêssegos 'Miraflores' mantidos a 15 e $20^{\circ} \mathrm{C}$, o ângulo de cor diminuiu, quando comparado com os frutos não resfriados, sendo maior nos frutos amadurecidos a $15^{\circ} \mathrm{C}$ do que nos amadurecidos a $20^{\circ} \mathrm{C}$. Girardi ${ }^{1}$ observou que frutos da cultivar Chiripá apresentaram alteração na cor durante o armazenamento e aquecimento intermitente, com o ângulo de cor sendo diminuído.

$\mathrm{O}$ amadurecimento envolve alterações que transformam $\mathrm{o}$ fruto completamente desenvolvido em um fruto pronto para o consumo. As alterações associadas com o amadurecimento incluem perda da cor verde e 
desenvolvimento das cores amarela, vermelha e outras tonalidades características de cada variedade. Com o amadurecimento, ocorre perda de firmeza, decréscimo na acidez e produção de compostos voláteis que dão o aroma característico do fruto.

A mudança na coloração dos frutos pode ser explicada pela intensidade do metabolismo, ou seja, quanto maior o metabolismo, mais intensa é a degradação da clorofila e a síntese de carotenóides (Chitarra \& Chitarra, 1990).

Ao analisar o resultado da análise sensorial (Figura 7), verifica-se que, de uma forma geral, os tratamentos com as menores notas, ou seja, os mais satisfatórios foram aqueles nos quais os frutos foram expostos a $20^{\circ} \mathrm{C}$ durante 48 horas e armazenados a $0^{\circ} \mathrm{C}$; frutos armazenados por dez dias a $0^{\circ} \mathrm{C}+48$ horas a $15^{\circ} \mathrm{C}+$ nove dias a $0^{\circ} \mathrm{C}$ e frutos armazenados por dez dias a $0^{\circ} \mathrm{C}+24$ horas a $38^{\circ} \mathrm{C}$ + dez dias a $0^{\circ} \mathrm{C}$ (Figura 7$)$.

Observou-se que, no que se refere à textura, os tratamentos onde os frutos foram expostos a $50^{\circ} \mathrm{C}$ durante uma hora e armazenados a $0^{\circ} \mathrm{C}$, e nos expostos a $50^{\circ} \mathrm{C}$ durante duas horas e armazenados a $0^{\circ} \mathrm{C}$, os resultados foram os mesmos obtidos com relação à lanosidade, com comportamento inferior ao controle, reforçando a idéia de que as altas temperaturas promovem um desequilíbrio maior do que as baixas temperaturas entre a poligalacturonase e pectinametilesterase, causando uma textura indesejável à polpa. 
Tabela 3. Ângulo de cor ('h) e Croma $\left(\mathrm{C}^{*}\right)$ obtidos em pêssegos 'Dourado-2' armazenados durante 30 dias a $0^{\circ} \mathrm{C}$ e $90-95 \%$ UR seguido de 3 dias de comercialização simulada a $25^{\circ} \mathrm{C}^{1}$

\begin{tabular}{llc}
\hline Tratamento & $\left({ }^{\circ} \mathrm{h}\right)^{2}$ & $\left(\mathrm{C}^{*}\right)^{2}$ \\
\hline Controle & $80,08^{\mathrm{a}}$ & $40,24 \mathrm{~cd}$ \\
Condicionamento Térmico & & \\
$50^{\circ} \mathrm{C} / 1 \mathrm{~h}$ & $78,89 \mathrm{ab}$ & $41,84 \mathrm{abc}$ \\
$50^{\circ} \mathrm{C} / 2 \mathrm{~h}$ & $77,73 \mathrm{abc}$ & $41,95 \mathrm{abc}$ \\
$38^{\circ} \mathrm{C} / 24 \mathrm{~h}$ & $69,15 \mathrm{e}$ & $39,43 \mathrm{~cd}$ \\
$20^{\circ} \mathrm{C} / 48 \mathrm{~h}$ & $80,13 \mathrm{a}$ & $45,50 \mathrm{a}$ \\
Aquecimento Intermitente & & \\
$25^{\circ} \mathrm{C} / 24 \mathrm{~h}$, a cada 5 dias & $71,20 \mathrm{de}$ & $42,68 \mathrm{abc}$ \\
$25^{\circ} \mathrm{C} / 48 \mathrm{~h}$, a cada 5 dias & - & - \\
$15^{\circ} \mathrm{C} / 24 \mathrm{~h}$, a cada 5 dias & $73,85 \mathrm{bcde}$ & $40,94 \mathrm{bc}$ \\
$15^{\circ} \mathrm{C} / 48 \mathrm{~h}$, a cada 5 dias & $71,02 \mathrm{de}$ & $41,64 \mathrm{abc}$ \\
$25^{\circ} \mathrm{C} / 48 \mathrm{~h}$, a cada 10 dias & $72,10 \mathrm{cde}$ & $45,08 \mathrm{a}$ \\
$15^{\circ} \mathrm{C} / 48$ h, a cada 10 dias & $75,39 \mathrm{abcd}$ & $44,66 \mathrm{ab}$ \\
$38^{\circ} \mathrm{C} / 24 \mathrm{~h}$ a cada 10 dias & $61,09 \mathrm{f}$ & $36,32 \mathrm{~d}$ \\
$\mathrm{C} . \mathrm{V} .(\%)$ & 3,37 & 3,92 \\
\hline
\end{tabular}

${ }^{1}$ Médias seguidas de mesma letra na coluna não diferem entre si, pelo teste de Tukey a 5\% de probabilidade

${ }^{2}$ Valores Iniciais : ${ }^{0} \mathrm{~h}=104,52 ; \mathrm{C}^{*}=36,21$.

A percepção e a aceitabilidade da textura são fatores importantes na avaliação da qualidade dos frutos e dos vegetais oferecidos no mercado. 
Embora a maioria dos consumidores mencione o sabor como o componente mais importante na qualidade do fruto, testes indicam que os consumidores são mais sensíveis à diferenças na textura do que no sabor. Os consumidores consideram a textura como um atributo positivo de qualidade que denota a frescância do produto e contribui para o prazer de comer. Em contraste com outros atributos sensoriais em alimentos, não existe um único e específico receptor para textura, isto devido a sua natureza múltipla (Konopacka e Plocharski, 2004). 


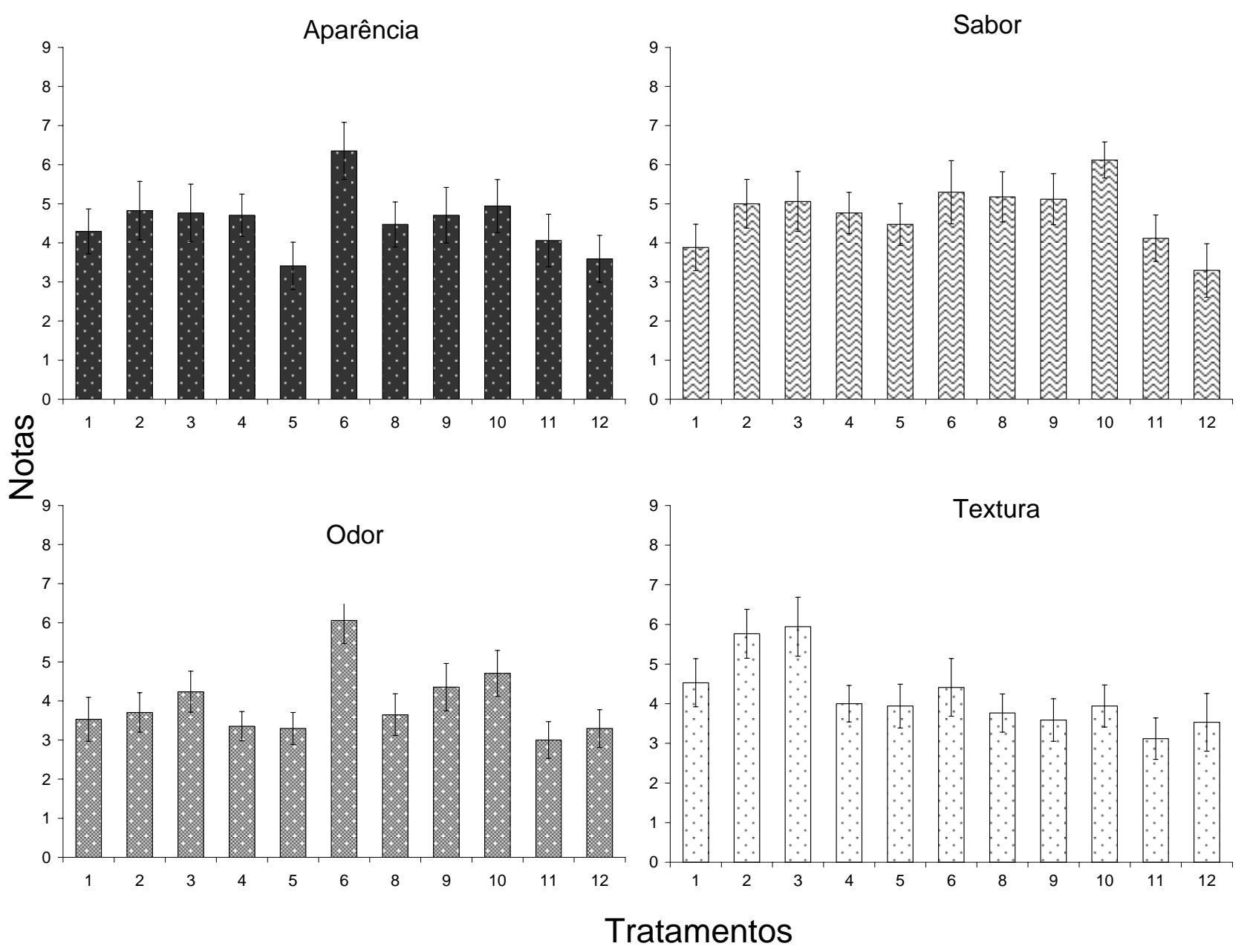

Figura 7 - Resultados da análise sensorial realizada em pêssegos 'Dourado 2' armazenados durante 30 dias a $0^{\circ} \mathrm{C}$ e $90-95 \%$ UR seguido de 3 dias de comercialização simulada a $25^{\circ} \mathrm{C}$. (Notas: 1=gostei extremamente; 3=gostei regularmente; $5=$ =não gostei nem desgostei; $7=$ desgostei regularmente; $9=$ desgostei extremamente $; \mathrm{T} 1=$ Frutos sem tratamento e armazenados a $0^{\circ} \mathrm{C}$ (controle e padrão de armazenamento); $\mathrm{T} 2=$ Frutos expostos a $50^{\circ} \mathrm{C}$ durante uma hora e armazenados a $0^{\circ} \mathrm{C} ; \mathrm{T} 3$ $=$ Frutos expostos a $50^{\circ} \mathrm{C}$ durante duas horas e armazenados a $0^{\circ} \mathrm{C} ; \mathrm{T} 4=$ Frutos expostos a $38^{\circ} \mathrm{C}$ durante 24 horas e armazenados a $0^{\circ} \mathrm{C} ; \mathrm{T} 5=$ Frutos expostos a $20^{\circ} \mathrm{C}$ durante 48 horas e armazenados a $0^{\circ} \mathrm{C}$; $\mathrm{T} 6=$ Frutos armazenados a $0^{\circ} \mathrm{C}$, com aquecimento a cada cinco dias a $25^{\circ} \mathrm{C}$ durante 24 horas; $\mathrm{T} 7=$ Frutos armazenados a $0^{\circ} \mathrm{C}$, com aquecimento a cada cinco dias a $25^{\circ} \mathrm{C}$ durante 48 horas; $\mathrm{T} 8=$ Frutos armazenados a $0^{\circ} \mathrm{C}$, com aquecimento a cada 
cinco dias a $15^{\circ} \mathrm{C}$ durante 24 horas; $\mathrm{T} 9=$ Frutos armazenados a $0^{\circ} \mathrm{C}$, com aquecimento a cada cinco dias a $15^{\circ} \mathrm{C}$ durante 48 horas; $\mathrm{T} 10=$ Frutos armazenados a $0^{\circ} \mathrm{C}$ por dez dias + 48 horas a $25^{\circ} \mathrm{C}+$ nove dias a $0^{\circ} \mathrm{C} ; \mathrm{T} 11=$ Frutos armazenados por dez dias a $0^{\circ} \mathrm{C}+48$ horas a $15^{\circ} \mathrm{C}+$ nove dias a $0^{\circ} \mathrm{C} ; \mathrm{T} 12=$ Frutos armazenados por dez dias a $0^{\circ} \mathrm{C}+24$ horas a $38^{\circ} \mathrm{C}+$ dez dias a $0^{\circ} \mathrm{C}$.

\subsection{Segundo experimento}

Na Figura 8 está representado um aspecto geral dos frutos, mostrando a evolução do amadurecimento após a aplicação dos tratamentos e conservação. Verificou-se que os tratamentos com aquecimento intermitente aceleraram o amadurecimento, devido à exposição às maiores temperaturas durante o aquecimento (Figura 8A e B), ao contrário do controle e condicionamento térmico, que evoluíram pouco à exposição a $0^{\circ} \mathrm{C}$, mas que completaram o amadurecimento, pelos menos visualmente, após 3 dias em temperatura ambiente (Figura 8C).

Observou-se que, após 30 dias de armazenamento, os frutos do controle apresentavam uma firmeza significativamente maior que a dos demais tratamentos, com exceção do condicionamento térmico à $50^{\circ} \mathrm{C}$ por 2 horas (Tabela 4). Nos frutos submetidos ao aquecimento intermitente, a firmeza se mostrou bastante reduzida logo após o armazenamento refrigerado $(<8,0 \mathrm{~N})$, sendo que após a exposição à temperatura ambiente a firmeza atingiu $<5,0 \mathrm{~N}$. No controle e nos frutos submetidos aos condicionamentos térmicos, a firmeza ainda era alta após 30 dias $(>40,0 \mathrm{~N})$, mas reduziu drasticamente na condição ambiente $(<10,0 \mathrm{~N})$, conforme Tabelas 4 e 5 . 

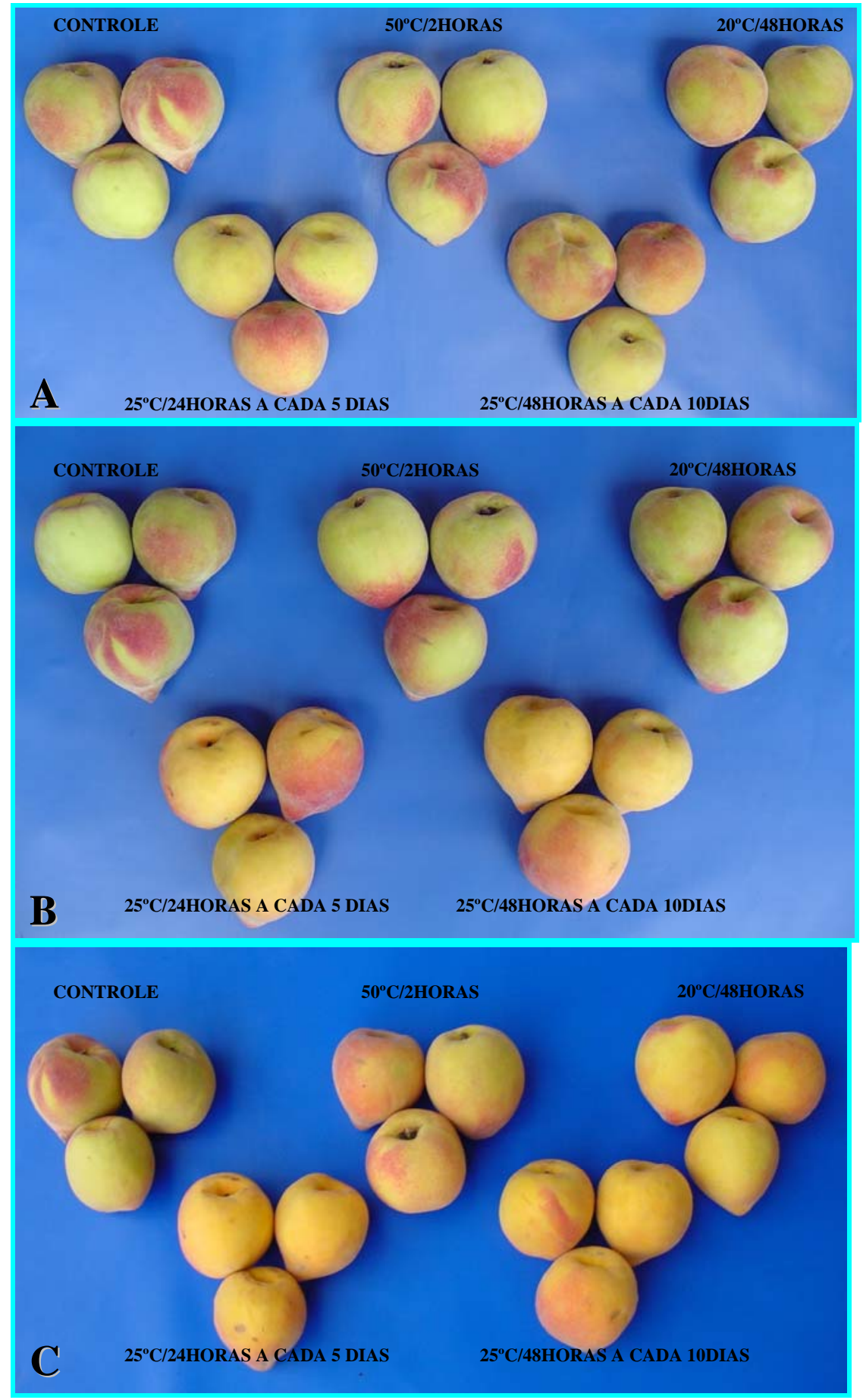

Figura 8 - Aspecto geral de pêssegos 'Dourado-2' submetidos a diferentes tratamentos e armazenados a $0^{\circ} \mathrm{C}$ e 90-95\% UR durante 17 dias (A), 30 dias (B) e após 3 dias de comercialização simulada a $25^{\circ} \mathrm{C}(\mathrm{C})$ 
Tabela 4. Firmeza da polpa, incidência de podridão e de lanosidade em pêssegos 'Dourado-2' armazenados durante 30 dias a $0^{\circ} \mathrm{C}$ e $90-95 \%$ $\mathrm{UR}^{1}$

\begin{tabular}{|c|c|c|c|}
\hline Tratamento & $\begin{array}{l}\text { Firmeza } \\
(\mathrm{N})^{2}\end{array}$ & $\begin{array}{c}\text { Incidência de } \\
\text { podridão }\end{array}$ & $\begin{array}{l}\text { Incidência de } \\
\text { lanosidade }^{4}\end{array}$ \\
\hline Controle & $52,99 a$ & $1,86 a$ & $2,14 b$ \\
\hline \multicolumn{4}{|l|}{ Condicionamento Térmico } \\
\hline $50^{\circ} \mathrm{C} / 2 \mathrm{~h}$ & $47,98 a$ & $1,14 b c$ & $1,94 b$ \\
\hline $20^{\circ} \mathrm{C} / 48 \mathrm{~h}$ & $19,98 b$ & $1,26 \mathrm{bc}$ & $4,38 \mathrm{a}$ \\
\hline \multicolumn{4}{|l|}{ Aquecimento Intermitente } \\
\hline $25^{\circ} \mathrm{C} / 24 \mathrm{~h}$, a cada 5 dias & $8,79 \mathrm{c}$ & $1,86 a$ & $4,22 \mathrm{a}$ \\
\hline $25^{\circ} \mathrm{C} / 48 \mathrm{~h}$, a cada 10 dias & $7,18 \mathrm{c}$ & $1,54 a b$ & $4,46 a$ \\
\hline C.V.(\%) & 14,33 & 16,03 & 8,23 \\
\hline \multicolumn{4}{|c|}{$\begin{array}{l}\text { Médias seguidas de mesma letra na coluna não diferem entre si, pelo teste de Tukey a } 5 \% \text { de } \\
\text { probabilidade. } \\
2 \text { Firmeza Inicial }=56,84 \mathrm{~N} \\
{ }^{3} 1=0 \%, 2<5 \%, 3=5-25 \%, 4=25-50 \% \text { e } 5=>50 \% \text { da área da superfície afetada; } \\
{ }^{4} 1=\text { fruto firme, com aparência de seco e nenhuma extração de suco; } 2 \text { = fruto firme, com } \\
\text { aparência de seco e alguma extração de suco; } 3=\text { fruto mole, com aparência de seco e nenhuma } \\
\text { extração de suco; } 4=\text { fruto mole, com aparência de seco e alguma extração de suco e } 5=\text { fruto } \\
\text { mole, com aparência de úmido e com muita extração de suco. }\end{array}$} \\
\hline
\end{tabular}


Tabela 5. Firmeza de polpa, incidência de podridão e de lanosidade em pêssegos 'Dourado-2' armazenados durante 30 dias a $0^{\circ} \mathrm{C}$ e 90-95\% UR seguido de 3 dias de comercialização simulada a $25^{\circ} \mathrm{C}^{1}$

\begin{tabular}{|c|c|c|c|}
\hline Tratamento & Firmeza $(\mathrm{N})^{2}$ & $\begin{array}{l}\text { Incidência de } \\
\text { podridão }^{3}\end{array}$ & $\begin{array}{l}\text { Incidência de } \\
\text { lanosidade }^{4}\end{array}$ \\
\hline Controle & $10,41 a$ & $1,22 \mathrm{c}$ & $3,48 b$ \\
\hline \multicolumn{4}{|l|}{ Condicionamento Térmico } \\
\hline $50^{\circ} \mathrm{C} / 2 \mathrm{~h}$ & $7,60 \mathrm{~b}$ & $1,42 \mathrm{bc}$ & $3,48 b$ \\
\hline $20^{\circ} \mathrm{C} / 48 \mathrm{~h}$ & $4,61 c$ & $1,64 b$ & $4,38 \mathrm{a}$ \\
\hline \multicolumn{4}{|l|}{ Aquecimento Intermitente } \\
\hline $25^{\circ} \mathrm{C} / 24 \mathrm{~h}$, a cada 5 dias & $5,09 c$ & $2,14 a$ & $4,64 \mathrm{a}$ \\
\hline $25^{\circ} \mathrm{C} / 48 \mathrm{~h}$, a cada 10 dias & $5,31 c$ & $1,78 \mathrm{ab}$ & $4,68 \mathrm{a}$ \\
\hline C.V. $(\%)$ & 15,51 & 13,41 & 3,99 \\
\hline \multicolumn{4}{|c|}{$\begin{array}{l}{ }^{1} \text { Médias seguidas de mesma letra na coluna não diferem entre si, pelo teste de Tukey a } 5 \% \text { de } \\
\text { probabilidade. } \\
{ }^{2} \text { Firmeza Inicial }=56,84 \mathrm{~N} \text {. } \\
{ }^{3} 1=0 \%, 2<5 \%, 3=5-25 \%, 4=25-50 \% \text { e } 5=>50 \% \text { da área da superfície afetada; } \\
{ }^{4} 1=\text { fruto firme, com aparência de seco e nenhuma extração de suco; } 2=\text { fruto firme, com } \\
\text { aparência de seco e alguma extração de suco; } 3=\text { fruto mole, com aparência de seco e nenhuma } \\
\text { extração de suco; } 4=\text { fruto mole, com aparência de seco e alguma extração de suco e } 5=\text { fruto } \\
\text { mole, com aparência de úmido e com muita extração de suco. }\end{array}$} \\
\hline
\end{tabular}


A firmeza em produtos hortícolas, medida através de métodos mecânicos, é frequentemente usada para determinar sua maturidade e grau de amadurecimento, sendo um importante componente da textura que influencia a percepção sensorial do fruto pelos consumidores (Konopacka e Plocharski, 2004). Durante o armazenamento, os frutos em amadurecimento, incluindo o pêssego, sofrem mudanças na textura, como uma substancial perda de firmeza (Hayama et al., 2003). A diminuição da perda da firmeza está relacionada com um declínio normal nas atividades metabólicas com a diminuição das temperaturas, inativação parcial da atividade da poligalacturonase resultando na redução da solubilização da pectina e amolecimento mais lento do fruto (Holland, 1993).

Ao compararmos os dois experimentos (Tabelas 1 e 5), verificamos que no primeiro, a firmeza do controle não diferiu significativamente da firmeza dos tratamentos que foram repetidos no segundo ano. Este fato não se repetiu no $2^{\underline{o}}$ experimento, ou seja, o desempenho dos tratamentos foi inferior ao do controle no que se refere à firmeza, mas de qualquer forma, os valores de firmeza foram bastante baixos.

A incidência de podridões foi baixa, não atingindo mais de $5 \%$ da superfície afetada (Tabela 4 e 5).

Após 30 dias de armazenamento refrigerado, os frutos submetidos ao aquecimento intermitente e os submetidos ao condicionamento por 48 horas a $20^{\circ} \mathrm{C}$, apresentavam um baixo índice de frutos com lanosidade (Tabela 4). Após 3 dias, esta tendência se manteve (Tabela 5).

No controle e no condicionamento térmico a $50^{\circ} \mathrm{C} / 2$ horas, após 30 dias, os frutos apresentaram-se com um índice de lanosidade menor do que o 
apresentado após 3 dias de comercialização simulada, caracterizando o período de latência da injúria pelo frio, a qual se desenvolve após a remoção do produto do armazenamento refrigerado (Fernández-Trujillo e Artés, 1998).

Na figura 9 pode-se verificar o sintoma de lanosidade manifestado nos frutos do controle.

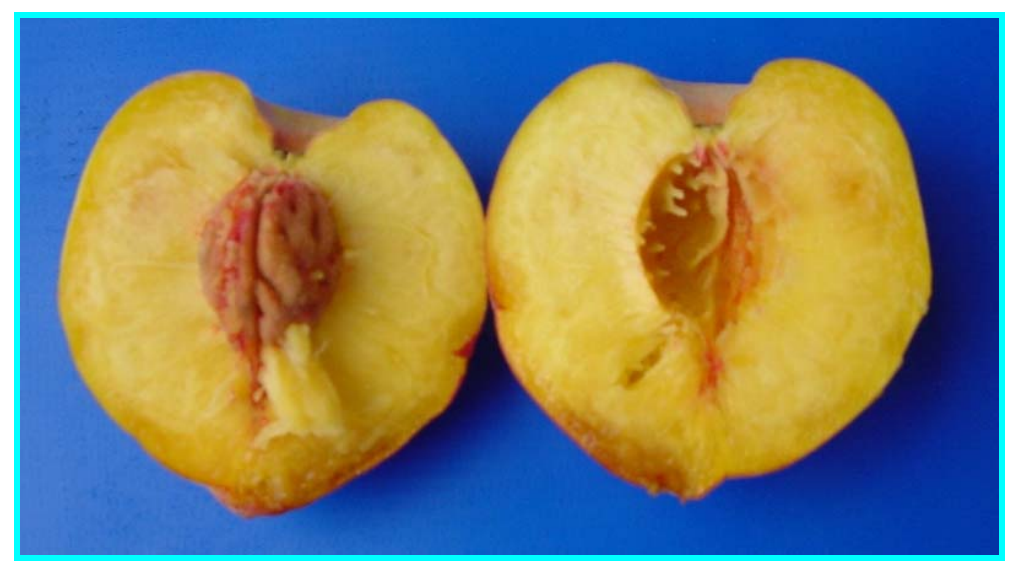

Figura 9 - Aspecto de fruto com lanosidade após o período de armazenamento refrigerado seguido de 3 dias de comercialização simulada

Os valores de vitamina C variaram de 0,00236 a 0,00343mg de ácido ascórbico/100 g de polpa (Tabela 6 e 7), confirmando a pouca quantidade de vitamina $C$ desta cultivar.

O teor de sólidos solúveis apresentou pouca variação entre os tratamentos durante o período de conservação e exposição à temperatura ambiente, atingindo valores entre 10,5 e 11,5Brix (Tabelas 6 e 7), sendo considerados normais para esta cultivar.

A acidez titulável variou de 0,35 e 0,45\% (Tabelas 6 e 7), embora tenha havido uma queda em relação à análise inicial $(0,535 \%)$, realizada antes dos 
frutos serem refrigerados. Os ácidos podem servir de substratos no processo respiratório, sendo, portanto, consumidos no processo (Chitarra \& Chitarra, 1990).

A relação SST/ATT não apresentou variações significativas em ambos os experimentos, embora os valores desta relação tenha sido mais baixo no experimento 2 do que no 1 , devido à menor acidez.

Foi verificado que o ângulo de cor quase não se modificou ou aumentou muito pouco com o tempo, passando da coloração avermelhada para a amarelada (Tabelas 8 e 9). 
Tabela 6. Teor de vitamina C, sólidos solúveis totais (SST), acidez total titulável (ATT), e relação SST/ATT em pêssegos 'Dourado-2' armazenados durante 30 dias a $0^{\circ} \mathrm{C}$ e $90-95 \%$ UR

\begin{tabular}{|c|c|c|c|c|}
\hline Tratamento & $\begin{array}{c}\text { Vit C } \\
\text { (mg ácido } \\
\text { ascórbico/100g) }{ }^{2}\end{array}$ & $\begin{array}{c}\text { SST } \\
\left({ }^{0} \text { Brix }\right)^{2}\end{array}$ & $\begin{array}{l}\text { ATT } \\
(\%)^{2}\end{array}$ & SST/ATT ${ }^{2}$ \\
\hline Controle & $0,00236 a$ & $10,84 a$ & $0,401 \mathrm{ab}$ & $27,18 a$ \\
\hline \multicolumn{5}{|l|}{ Condicionamento Térmico } \\
\hline $50 \circ \mathrm{C} / 2 \mathrm{~h}$ & $0,00254 a$ & $10,94 a$ & $0,421 b$ & $26,32 \mathrm{ab}$ \\
\hline $20^{\circ} \mathrm{C} / 48 \mathrm{~h}$ & 0,00271a & $11,46 a$ & $0,526 a$ & $21,96 b$ \\
\hline \multicolumn{5}{|l|}{ Aquecimento Intermitente } \\
\hline $25^{\circ} \mathrm{C} / 24 \mathrm{~h}$, a cada 5 dias & $0,00272 \mathrm{a}$ & $10,98 a$ & $0,449 \mathrm{ab}$ & $24,58 \mathrm{ab}$ \\
\hline $25^{\circ} \mathrm{C} / 48 \mathrm{~h}$, a cada 10 dias & $0,00343 a$ & $11,26 a$ & $0,465 \mathrm{ab}$ & $24,38 \mathrm{ab}$ \\
\hline C.V. (\%) & 30,76 & 3,77 & 10,00 & 10,96 \\
\hline
\end{tabular}

${ }^{1} \overline{\text { Médias seguidas de mesma letra na coluna não diferem entre si, pelo teste de Tukey a } 5 \% \text { de }}$ probabilidade.

2 Valores Iniciais: Vit C = 0,003587mg de ácido ascórbico/100g; SST = 10,70 Brix; ATT = 0,535\%; $\mathrm{SST} / \mathrm{ATT}=20,00$. 
Tabela 7. Teor de vitamina C, sólidos solúveis totais (SST), acidez total titulável (ATT), e relação SST/ATT em pêssegos 'Dourado-2' armazenados durante 30 dias a $0^{\circ} \mathrm{C}$ e $90-95 \%$ UR seguido de 3 dias de comercialização simulada a $25^{\circ} \mathrm{C}^{1}$

\begin{tabular}{|c|c|c|c|c|}
\hline \multirow{4}{*}{ Tratamento } & Vit C & \\
\hline & & & ATT & \multirow{3}{*}{ SST/ATT ${ }^{2}$} \\
\hline & (mg ácido & SST & \multirow{2}{*}{$(\%)^{2}$} & \\
\hline & ascórbico/100g) & $\left({ }^{0} \mathrm{Brix}\right)^{2}$ & & \\
\hline Controle & $0,00342 \mathrm{a}$ & $11,52 a$ & $0,432 a$ & $26,83 a$ \\
\hline \multicolumn{5}{|l|}{ Condicionamento Térmico } \\
\hline $50 \circ \mathrm{C} / 2 \mathrm{~h}$ & $0,00332 a$ & $11,42 a$ & $0,405 a b$ & $28,21 a$ \\
\hline $20^{\circ} \mathrm{C} / 48 \mathrm{~h}$ & 0,00337a & $11,04 a$ & $0,380 \mathrm{ab}$ & $29,05 a$ \\
\hline \multicolumn{5}{|l|}{ Aquecimento Intermitente } \\
\hline $25^{\circ} \mathrm{C} / 24 \mathrm{~h}$, a cada 5 dias & $0,00341 \mathrm{a}$ & $10,76 a$ & $0,355 b$ & $30,34 a$ \\
\hline $25^{\circ} \mathrm{C} / 48 \mathrm{~h}$, a cada 10 dias & 0,00293a & $10,72 \mathrm{a}$ & $0,366 b$ & $29,43 a$ \\
\hline C.V. (\%) & 17,31 & 4,40 & 8,25 & 7,18 \\
\hline
\end{tabular}

${ }^{1}$ Médias seguidas de mesma letra na coluna não diferem entre si, pelo teste de Tukey a 5\% de probabilidade.

${ }^{2}$ Valores Iniciais: Vit C = 0,00358mg de ácido ascórbico/100g; SST = 10,70 Brix; ATT = 0,535\%; $\mathrm{SST} / \mathrm{ATT}=20,00$. 
Tabela 8. Ângulo de cor ( $(\mathrm{h})$ e Croma $\left(\mathrm{C}^{*}\right)$ obtidos em pêssegos 'Dourado-2' armazenados durante 30 dias a $0^{\circ} \mathrm{C}$ e $90-95 \% \mathrm{UR}^{1}$

\begin{tabular}{lcc}
\hline Tratamento & $\left({ }^{\circ}\right)^{2}$ & $\left(\mathrm{C}^{*}\right)^{2}$ \\
\hline Controle & $79,98 \mathrm{~b}$ & $34,01 \mathrm{~b}$ \\
Condicionamento Térmico & & \\
$50^{\circ} \mathrm{C} / 2 \mathrm{~h}$ & $78,91 \mathrm{~b}$ & $35,81 \mathrm{~b}$ \\
$20^{\circ} \mathrm{C} / 48 \mathrm{~h}$ & $80,78 \mathrm{~b}$ & $34,72 \mathrm{~b}$ \\
Aquecimento Intermitente & & \\
$25^{\circ} \mathrm{C} / 24 \mathrm{~h}$, a cada 5 dias & $83,40 \mathrm{a}$ & $39,82 \mathrm{a}$ \\
$25^{\circ} \mathrm{C} / 48 \mathrm{~h}$, a cada 10 dias & $78,93 \mathrm{~b}$ & $34,43 \mathrm{~b}$ \\
C.V .(\%) & 1,57 & 4,06
\end{tabular}

${ }^{1}$ Médias seguidas de mesma letra na coluna não diferem entre si, pelo teste de Tukey a 5\% de probabilidade.

2 Valores Iniciais : ${ }^{\circ} \mathrm{h}=77,07 ; \mathrm{C}^{*}=33,22$. 
Tabela 9. Ângulo de cor ( $\left.{ }^{\circ} \mathrm{h}\right)$ e Croma $\left(\mathrm{C}^{*}\right)$ obtidos em pêssegos 'Dourado-2' armazenados durante 30 dias a $0^{\circ} \mathrm{C}$ e $90-95 \%$ UR seguido de 3 dias de comercialização simulada a $25^{\circ} \mathrm{C}^{1}$.

\begin{tabular}{|c|c|c|}
\hline Tratamento & $(\mathrm{oh})^{2}$ & $\left(C^{*}\right)^{2}$ \\
\hline Controle & $84,89 a$ & $40,21 \mathrm{c}$ \\
\hline \multicolumn{3}{|l|}{ Condicionamento Térmico } \\
\hline $50^{\circ} \mathrm{C} / 2 \mathrm{~h}$ & $84,29 a$ & $41,85 b c$ \\
\hline $20^{\circ} \mathrm{C} / 48 \mathrm{~h}$ & $81,93 a$ & $43,97 \mathrm{ab}$ \\
\hline \multicolumn{3}{|l|}{ Aquecimento Intermitente } \\
\hline $25^{\circ} \mathrm{C} / 24 \mathrm{~h}$, a cada 5 dias & $76,42 b$ & $44,50 \mathrm{a}$ \\
\hline $25^{\circ} \mathrm{C} / 48 \mathrm{~h}$, a cada 10 dias & $76,20 \mathrm{~b}$ & $43,50 \mathrm{ab}$ \\
\hline C.V. $(\%)$ & 2,03 & 2,84 \\
\hline
\end{tabular}

Ao analisarmos a taxa respiratória e a liberação de etileno dos frutos (Figura 10), verificamos que todos os tratamentos se comportaram de forma semelhante, ou seja, mantiveram a taxa respiratória num nível relativamente constante enquanto no armazenamento refrigerado, com picos quando da aplicação dos tratamentos térmicos, o mesmo ocorrendo com a liberação do etileno.

Os frutos do controle mantiveram sua taxa respiratória baixa durante todo o período de armazenamento, elevando-se drasticamente assim que 
retirada a condição refrigerada. $\mathrm{O}$ pico de liberação de etileno apareceu dois dias depois.

Nos frutos submetidos ao condicionamento térmico, após os tratamentos, foi observada uma elevação na taxa respiratória logo após a retirada dos frutos dos mesmos (após duas horas e 2 dias de tratamento), sem ocorrer, no entanto, liberação de etileno neste mesmo período. Após 30 dias de armazenamento refrigerado, a taxa de liberação de etileno nos frutos submetidos a $20^{\circ} \mathrm{C} / 48$ horas, foi bem maior do que a observada nos submetidos a $50^{\circ} \mathrm{C} / 2$ horas (58,4 e $1,65 \mu \mathrm{L} \mathrm{C} \mathrm{C}_{4} \mathrm{~kg}^{-1} \mathrm{~h}^{-1}$, respectivamente), atingindo valores ainda mais altos durante e após o período de comercialização simulada. Este comportamento pode ser devido a diminuição da habilidade da enzima ACC oxidase em transformar ACC em etileno devido as injúrias pelo frio (MartínezRomero et al., 2003), já que a incidência de lanosidade neste tratamento foi significativamente igual ao controle. A atividade da ACC oxidase foi menor em abóboras e nectarinas injuriadas pelo frio do que nos frutos sadios (McCollum et al., 1995; Zhou et al., 2001) e foi inibida em cherimóias armazenadas sob temperaturas causadoras de "chilling". Tem sido proposto que temperaturas maiores do que $35^{\circ} \mathrm{C}$ causam o acúmulo endógeno de $\mathrm{ACC}$ em tecidos de maçãs, devido à inativação progressiva da ACC oxidase (Klein e Lurie, 1991). Em kiwi, foi comprovado que a conversão de ACC em etileno é ótima em temperatura de $30^{\circ} \mathrm{C}$, diminui em torno de $60 \%$ ao reduzir a temperatura até $15^{\circ} \mathrm{C}$ e em torno de $40 \%$, ao aumentá-la até $35^{\circ} \mathrm{C}$. A conversão não ocorre quando os frutos são expostos a $40^{\circ} \mathrm{C}$, mesmo que, posteriormente, retornem a temperaturas mais amenas (Paull \& Chen., 1990). 
$\mathrm{O}$ aquecimento intermitente promoveu um aumento na taxa respiratória e de liberação de etileno após todas as aplicações, em ambos os intervalos. O etileno apareceu primeiramente nos frutos aquecidos a cada 5 dias, 1 semana antes dos frutos aquecidos a cada 10 dias, devido a maior exposição dos frutos a altas temperaturas. Segundo Abeles et al. (1992), a temperatura ótima para a biossíntese de etileno situa-se entre 20 e $28^{\circ} \mathrm{C}$. Nos frutos do controle e nos submetidos ao condicionamento térmico, os picos de respiração e etileno foram no mesmo dia, ou seja, após 3 dias a $25^{\circ} \mathrm{C}$. Nos tratamentos com aquecimento intermitente, os picos não coincidiram.

Fernandez-Trujillo et al. (2000) observaram que, ao armazenar pêssegos 'Miraflores' em temperaturas de 15 e $20^{\circ} \mathrm{C}$ por 10 dias, o pico respiratório foi relativamente uniforme até o climatério, o qual apareceu no 6o dia. Os picos respiratório e de etileno foram no mesmo dia a $15^{\circ} \mathrm{C}$. Foi observado que, um aumento continuo em ambas as atividades após 1 semana a $15^{\circ} \mathrm{C}$ comparado $\operatorname{com} 20^{\circ} \mathrm{C}$ poderiam ser sintomas de desorganização dos tecidos. Isto é um efeito comum em frutos com injúrias pelo frio não severas, em comparação com pêssegos afetados por lanosidade severa onde ambas as atividades foram menores do que em frutos saudáveis, efeito este observado nos frutos mantidos a $50^{\circ} \mathrm{C} / 2$ horas, no presente experimento. 

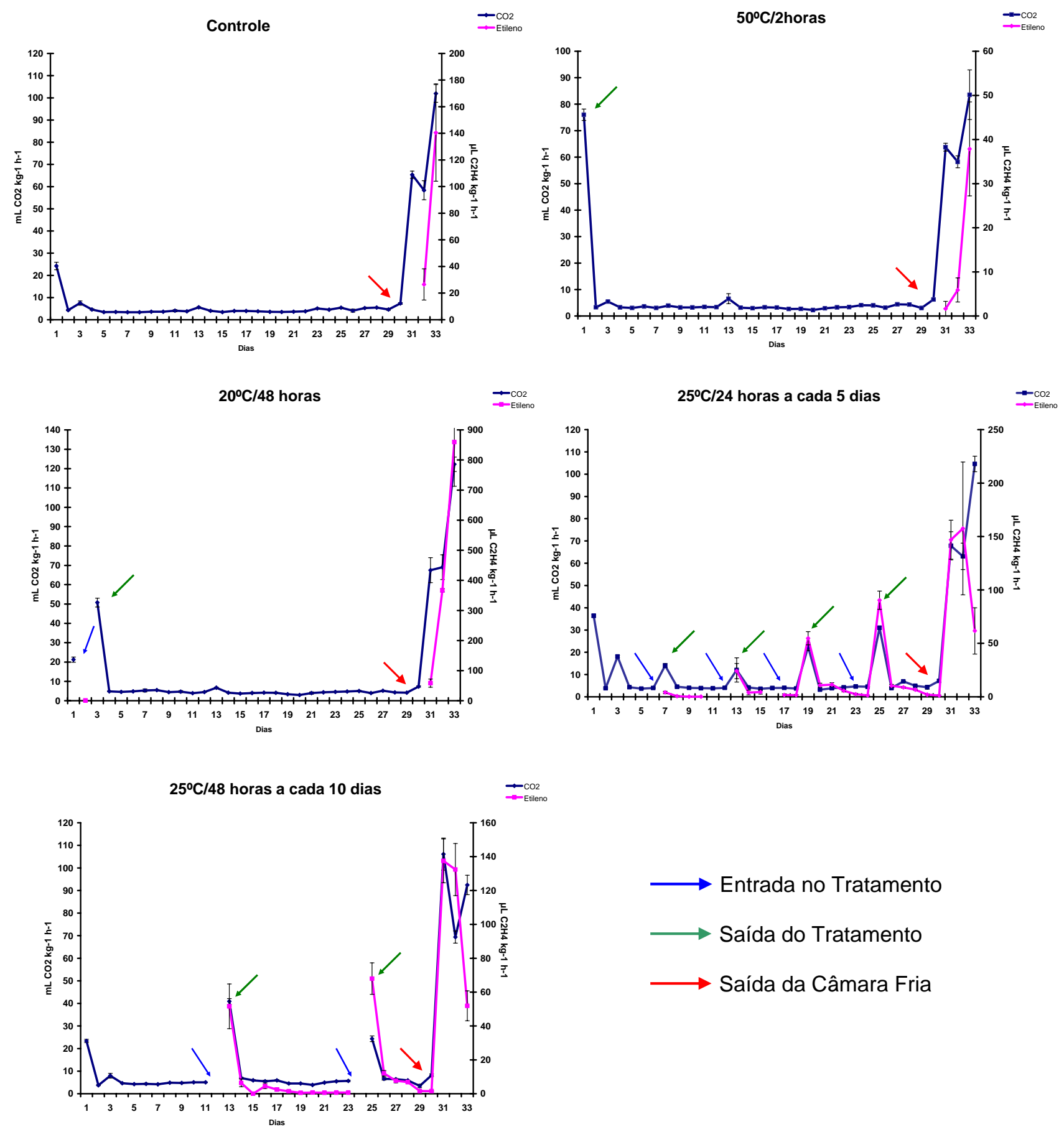

Figura 10 - Atividade respiratória e taxa de liberação de etileno em pêssegos ‘Dourado-2' armazenados durante 30 dias a $0^{\circ} \mathrm{C}$ e 90-95\% UR, seguido de 3 dias de comercialização simulada a $25^{\circ} \mathrm{C}$ 


\section{CONCLUSÕES}

\section{Primeiro experimento}

- O aquecimento intermitente se mostrou mais eficiente no controle da lanosidade que o condicionamento térmico, sem afetar parâmetros importantes de qualidade, principalmente a firmeza. Apesar de apresentarem maior perda de massa ao final do período de armazenamento refrigerado, após o período de comercialização simulada este efeito se tornou não significativo.

- Os tratamentos nos quais os frutos foram submetidos ao aquecimento intermitente na forma de aquecimento a cada cinco dias a $25^{\circ} \mathrm{C}$ durante 24 horas; aquecimento a cada cinco dias a $15^{\circ} \mathrm{C}$ durante 24 horas; aquecimento a cada cinco dias a $15^{\circ} \mathrm{C}$ durante 48 horas; aquecimento a cada dez dias a $25^{\circ} \mathrm{C}$ durante 48 horas e aquecimento a cada dez dias a $15^{\circ} \mathrm{C}$ durante 48 horas se mostraram eficientes no controle da lanosidade.

\section{Segundo experimento}

- O aquecimento intermitente com ciclos de 5 ou 10 dias e o condicionamento térmico a $20^{\circ} \mathrm{C}$ durante 48 horas podem ser utilizados para reduzir a incidência de lanosidade em pêssegos 'Dourado-2' armazenados durante 30 dias a $0^{\circ} \mathrm{C}$. 
- Estes tratamentos não afetam fortemente as características físicoquímicas, com a exceção da maior perda de firmeza. Mesmo com esta desvantagem, os tratamentos não trazem grandes prejuízos, considerando que a Dourado-2 é uma cultivar de mesa. Entretanto, maiores cuidados no transporte e comercialização devem ser tomados após a retirada das frutas do armazenamento. Ainda, dada a maior facilidade de aplicação, o condicionamento térmico a $20^{\circ} \mathrm{C}$ durante 48 horas poderia ser facilmente adotado pela cadeia produtiva.

- Os tratamentos térmicos podem incrementar a tolerância do produto às baixas temperaturas e possibilitar o armazenamento por um maior período de tempo. Entretanto, não só o conhecimento dos efeitos dos tratamentos de controle de injúrias pelo frio é importante, mas também a viabilidade prática e econômica da técnica que, uma vez estabelecida, podem tornar o tratamento aplicável em nível comercial. 


\section{REFERÊNCIAS BIBLIOGRÁFICAS}

ABELES, F.B.; MORGAN, P.W.; SALTVEIT, M.E. Ethylene in plant biology. San Diego: Academic Press, 1992, 414p.

AKBUDAK, B.; ERIS, A. Physical and chemical changes in peaches and nectarines during the modified atmosphere storage. Food Control, v.15, p.307-313, 2004.

ANDERSON, R.E.; PENNEY, R.W. Intermittent warming of peaches and nectarines stored in a controlled atmosphere or air. Journal of American Society of Horticultural Science, v.100, p.151-153, 1975.

ARTÉS, F. Innovaciones en los tratamientos físicos para preservar la calidad de los productos hortofrutícolas em la postrecolecion. I. Pretratamientos térmicos. Revista Española de Ciencia y Tecnologia de Alimentos, v.35, n.1, p.45-64, 1995.

ARTÉS, F.; ESCRICHER, A.J. Intermittent warming reduces chilling injury and decay of tomato fruit. Journal Food Science, v.59, p.1053-1056, 1994.

ARTÉS, F.; CANO, A.; FERNÁNDEZ-TRUJILLO, J.P. Pectolytic enzyme activity during intermittenr warming storage of peaches. Journal of Food Science, v.61, n.2, p.311313, 1996.

AWAD, M. Fisiologia pós-colheita de frutos. São Paulo: Nobel, 1993. 116p.

BEN-AIRE, R.; LAVEE, S.; GUELFAT-REICH, S. Control of woolly breakdown of 'Elberta' peaches in cold storage, by intermittent exposure to room temperature. Journal of American Society of Horticultural Science, v. 95, p.801-803, 1970. 
BIALE, J.B. The postharvest biochemistry of tropical and subtropical fruits. Advances in Food Research, v.10, p.293-354, 1960.

BOYES, W.W. The development of woolliness in South African peaches during cold storage. IN: IV Int. Refrig. Congress, Paris, 1955. Proceedings. v.4, p.533-537, 1955.

BRADY, J.C. Biochemistry of fruit ripening. London: Chaprnan \& Hall, 1993.

BRON, I.U. ; JACOMINO, A.P. ; APPEZZATO-DA-GLÓRIA, B. ; Alterações anatômicas e fisico-químicas associadas ao armazenamento refrigerado de pêssegos 'Aurora-1' e 'Dourado-2'. Pesquisa agropecuária brasileira, v.37, n.10, p.1349-1358, 2002.

BROVELLI, E.A.; BRECHT, J.K.; SHERMAN, W.B. Anatomical and physiological responses of melting and nonmelting - flesh peaches to postharvest chilling. Journal of the American Society of Horticultural Science, v.123, n.4, p.668-674, 1998.

BROVELLI, E.A.; BRECHT, J.K.; SHERMAN, W.B.; SIMS, C.A. Nonmelting-flesh trait in peaches is not related to low ethylene production rates. Journal of the American Society of Horticultural Science, Alexandria, v.34, n.2, p.313-315, 1999.

CARVALHO, C.R.L.; MANTOVANI, D.M.B.; CARVALHO, P.R.N.; MORAES, R.M.M. Análises químicas de alimentos. Campinas: ITAL, 1990. 121p. (ITAL, Manual Técnico)

CHAN, H.T.; FORBUS, W.B. Delayed light emission as a biochemical indicator of papaya heat treatment. Journal of Food Science, v.53, p.1490-1492, 1988.

CHITARRA, M.I. ; CHITARRA, A.B. Pós-colheita de frutos e hortaliças: fisiologia e manuseio. Lavras: ESAL/FAEPE, 1990. 320p.

CHOI, J.H. ; LEE, S.K. Effect of pre-ripening on woolliness of peache. Acta Horticuturae, v.553, p.281-283, 2001. 
CRISOSTO, C.H.; LABAVITCH, J.M. Developing a quantitative method to evaluate peach (Prunus Persica) flesh mealiness. Postharvest Biology and Technology, v.25, p.151-158, 2002.

DONG, L.; ZHOU, H.W.; SONEGO, L.; LERS, A.; LURIE, S. Ethylene involvement in the cold nstorage disorder of 'Flavortop' nectarine. Postharvest Biology and Technology, v.23, p.105-115, 2001.

DUNLAP, J.R.; LINGLE, S.E.; LESTER, G.E. Ethylene production in netted muskmelon subjected to postharvest heating and refrigerated storage. HortScience, v.25, p.207$209,1990$.

FAN, X; BLANKENSHIP, S.M.; MATTHEIS, J.P. 1-Methylcyclopropene inhibits apple ripening. Journal of the American Society of Horticultural Science, v.124, p.690695, 1999.

FNP Consultoria \& Comércio. Agrianual: anuário da agricultura brasileira. São Paulo, 2000. 545 p.

FNP Consultoria \& Comércio. Agrianual: anuário da agricultura brasileira. São Paulo, 2004. 498 p.

FERNANDEZ, M.A.F., Influência da atmosfera modificada e armazenamento no escurecimento interno de pêssegos cv. Marli. Lavras, 2000. 113p. Dissertação. (Mestrado) - Universidade Federal de Lavras.

FERNÁNDEZ-TRUJILLO, J.P. ; ARTÉS, F. Keeping quality of cold stored peaches using intermittent warming. Food Research International, v.30, n.6, p.441-450, 1997.

FERNÁNDEZ-TRUJILLO, J.P. ; ARTÉS, F. Chilling injuries in peaches during conventional and intermittent warming storage. International Journal of Refrigeration, v.21, n.4, p.265-272, 1998. 
FERNÁNDEZ-TRUJILLO, J.P. ; CANO, A.; ARTÉS, F. Interactions among cooling, fungicide and postharvest ripening temperature on peaches. International Journal of Refrigeration, v.23, p.457-465, 2000.

FIELD, R.J. The effect of temperature on ethylene production by plant tissue. In: ROBERTS, J.A.; TUCKER, G.A. (Ed.) Ethylene and plant development. London: Butterworths, 1984. p.47-69.

GIL, M.I. ; TOMÁS-BARBERÁN, F.A. ; HESS-PIERCE, B. ; KADER, A.A. Antioxidant capacities, phenolic compounds, carotenoids, and vitamin C contents of nectarine, peach, and plum cultivars from California. Journal of Agricultural and Food Chemistry,v.50, p.4976-4982, 2002.

GONÇALVES, N.B. Efeito da aplicação de cloreto de cálcio associado ao tratamento hidrotérmico sobre a composição química e suscetibilidade ao escurecimento interno do abacaxi 'Smooth cayenne'. Lavras, 1998. 101p. Tese (Doutorado) Universidade Federal de Lavras.

GONZÁLEZ-AGUILAR, G.A.; GAYOSSO, L.; CRUZ, R.; FORTIZ, J.; BÁEZ, R.; WANG, C.Y. Polyamines ainduced by hot water treatments reduce chilling injuty and decay in pepper fruit. Postharvest Biology and Technology, v.18, p.19-26, 2000.

HAYAMA, H.; ITO, A.; MORIGUCHI, T.; KASHIMURA, Y. Identification of a new expansin gene closely associated with peach fruit softening. Postharvest Biology and Technology, v.29, p.1-10, 2003.

HARDENBURG, R.E.; WATADA, A.E.; WANG, C.Y. The commercial storage of frits, vegetables, and florist, and nursery stocks. Washington: USDA, 1986. 130p. (USDA. Agriculture Handbook, 66).

HOLLAND, N. Conservação pós-colheita de pêssegos (cv. 'Biuti'): interação entre cálcio e temperatura, Lavras, 1993. 116p. Dissertação (Mestrado) - Escola Superior de Agronomia de Lavras. 
JOHN, P. Ethylene biosynthesis: The role of 1-aminocyclopropane-1-carboxylate (ACC) oxidaser, and its possible evolutionary origin. Physiology Plantariumm, v.100, p.583-592, 1997.

JONES, W.W. The influence of relative humidity on the respiration of papaya at hight temperature. Journal of the American Society for Horticultural Science., v.37, p.124-199, 1939.

JU, Z.; DUAN, Y.; JU, Z. Leathrines and mealines of peaches in relation to fruit maturity and storage temperature. Journal of Horticultural Science \& Biotechnology, v.75, n.1, p.86-91, 2000.

KAILASAPATHY, K.; MELTON, L.D. Woolliness in stone fruits. Asian Food Journal, v.7, p.13-16, 1992.

KANELLIS, A.K.; SOLOMOS, T.; ROUBELAKS-ANGELAKIS, K.A. Supression of cellulose and poligalacturonase and induction of alcohol deydrogenase isoenzymes in avocado fruit mesocarp subjected to low oxygen stress. Plant Physiology, v.96, p.269-274, 1991.

KETSA, S.; DAENGKANIT, T. Firmness and activities of poligalacturonase, pectinesterase, $\beta$-galactosidase and cellulose in ripening durian harvested at different stages of maturity. Scientia Horticulturae, v.80, p.181-188, 1999.

KLEIN, J.D.; LURIE, S. Prestorage heat treatment as a means of improving poststorage quality of apples. Journal of the American Society for Horticultural Science, v.115, n.2, p.265-269, 1990.

KLEIN, J.D.; LURIE, S. Postharvest heat treatment and fruit quality. Postharvest New and Information, v.2, n.1, p.15-19, 1991.

KLUGE, R.A.; HOFFMANN, A.; NACHTIGAL, J.C.; BILHALVA, A.B.; FACHINELLO, J.C. Aquecimento intermitente em pêssegos 'Br-6' frigoconservados. Pesquisa Agropecuária Brasileira, v. 31, n.8, p. 543-547, 1996. 
KLUGE, R.A.; NACHTIGAL, J.C.; FACHINELLO, J.C.; BILHALVA, A.B. Fisiologia e manejo pós-colheita de frutas de clima temperado. 2.ed. Campinas:.Livraria e Editora Rural, 2002. 214p.

KLUGE, R.A.; NACHTIGAL, J.C.; HOFFMANN, A.; BILHALVA, A.B.; FACHINELLO, J.C.Efeito de esters de sacarose sobre pêssegos 'Br-6' refrigerados. Pesquisa agropecuária Brasileira, v.33, n.2, p.109-114, 1998.

KONOPACKA, D.; PLOCHARSKI, W.J. Effect of storage condintions on the relationship between apple firmness and texture acceptability. Postharvest Biology and technology, v.32, p.205-211, 2004.

LELIÈVRE, J.M.; LATCHE, A.; JONES, B.; BOUZAYEN, M.; PECH, J.C. Ethylene and fruit ripening. Physiology Plantarium, v.101, p.727-739, 1997.

LILL, R.E. ; O’DONAGHUE, E.M. ; KING, G.A. Postharvest physiology of peaches and nectarines. Horticultural Reviews, v.11, p.413-452, 1989.

LI-PING, L.; TAO, H. Storage of 'Okuba' peaches after heat shock treatment. Acta Horticulturae, n.464, p.315-320, 1998.

LUCHSINGER, L.E. ; WALSH, C.S. Chilling injury of peach fruit during storage. Acta Horticulturae, v.464, p.473-477, 1998.

LUCHSINGER, L.E. Control de fisiopatias en frutos de carozo (hueso). In: CONGRESSO Iberoamericano de tecnologia postcosecha y agroexportaciones, 3., Simposio: Control de fisiopatias en frutas durante el almacenamiento en frio, 3. , 2000, Santa Fé de Bogotá, 2000. Proceedings Colombia, 2000. p.87-93.

LURIE, S. Postharvest heat treatments. Postharvest Biology and Technology, v.14, p.257-269, 1998.

LURIE, S.; KLEIN, J.D. Heat treatment of ripening apples: differential effects on physiology and biochemistry. Physiologia Plantarium, v.78, n.2, p.181-186, 1990. 
LURIE, S.; KLEIN, J.D. Acquisition of low temperature tolerance in tomatoes by exposure to high temperature stress. Journal American Society of Horticultural Science, v.116, p.1007-1012, 1991.

LURIE, S.; NUSSINOVICH, A. Compression characteristics, firmness, and texture perception of heat treated and unheated apples. Journal Food Science Technology, v.31, p.1-5, 1996.

LUZA, J.G.; van GORSEL, R.; POLITO, V.S.; KADER, A.A. Chilling injury in peaches: a cytochemical and ultrastrutural cell wall study. Journal of the American Society for Horticultural Science, v.117, n.1, p.114-118, 1992.

MARTÍNEZ-ROMERO, D.; SERRANO, M.; VALERO, D. Physiological changes in pepino (Solanum muricatum Ait.) fruit stored at chilling and non-chilling temeratures. Postharvest Biology and Technology. v.30, p.177-186, 2003.

McCOLLUM, T.G.; D'AQUINO, S.; McDONALD, R.E. Heat treatment inhibits mango chilling injury. HortScienc,. v.28, p.197-198, 1993.

McCOLLUM, T.G.; DOOSTDAR, H.; MAYER, R.T.; McDONALD, R. E. Immersion of cucumber fruit in heated water alters chilling-induced physiological changes. Postharvest Biology and technology, v.6, p.55-64, 1995.

McGUIRRE, R.G. Reporting of objective color measurements. HortScience, v.27, n.12, p.1254-1255, 1992.

MITCHAM, E.J.; McDONALD, R.E. Respiration rate, internal atmosphere, and ethanol and acetaldehyde accumulation in heat treated mango fruit. Postharvest Biology and Technolog, v.3, p.77-86, 1993.

MITCHELL, F.G.; MAYER, G.; MAXIE, E.C.; COATES, W.W. Cold storage effects on fresh market peaches, nectarines and plums: I. estimating freezing points, II. Using low temperatures to delay internal breakdown. Californian. Agriculture., v.28, p.12-14, 1974. 
NANOS, G.D.; MITCHELL, F.G. High-temperature conditioning to delay internal breakdown development in peaches and nectarines. HortScience, v.26, n.7, p.882885, 1991.

NUNES, E.E. Conservação pós-colheita de pêssegos 'Premier' tratados com cálcio e armazenados em condições ambiente. Lavras, 2003. 41p. Dissertação (Mestrado) Universidade Federal de Lavras.

OBENLAND, D.M.; CRISOSTO, C.H.; ROSE, J.K.C. Expansin protein levelsdecline with the development of mealiness in peaches. Postharvest Biology and Technology, v.29, p.11-18, 2003.

OJIMA, M.; DALL'ORTO, F.A.C.; BARBOSA, W.; TOMBOLATO, A.F.C.; RIGITANO, O. ; SCARANARI, H.J.; MARTINS, F.P.; SANTOS, R.R. 'Dourado-1'e 'Dourado-2': Novos cultivares de pêssego amarelo para mesa. Bragantia, v.44, n.1, p.451-455, 1985.

ORR, G.; BRADY, C.J. Rela tionship of endopolygalacturonase activity to fruit softening in a freestone peach. Postharvest Biology and Technology, v.3, p.121-130, 1993.

PAULL, R.E.; CHEN, N.J. Heat shock response in field-grown, ripening papaya fruit. Journal American Society of Horticultural Science, v.115, p.623-631, 1990.

PAULL, R.E.; CHEN, N.J. Heat treatment and fruit ripening. Postharvest Biology and Technology, v.21, p.21-37, 2000.

PEANO, C.; GIACALONE, G.; BOUNOUS, G. Changes in fruit quality of peaches and nectarine from transport to shelf. Acta Horticulturae, v. 533, p.739-740, 2001.

SALUNKHE, D.K.; DESAI, B.B. Postharvest biotechnology of fruits. Boca Raton:CRC Press, 1984. v.2, 147p.

SHEWFELT, R.L. Stress physiology: a cellular approach to quality. In: SHEWFELT, R.L.; PRUSSIA, S.E. (Ed.). Postharvest Handling: a systems approach. New York: Academic Press, 1993. cap. 12, p. 257-276. 
SISLER, E.C.; JUPILLE, E.; SEREK, M. Effects of 1-methylcyclopropene and methylenecyclopropane on ethylene binding and ethylene action on cut carnations. Plant Growth Regulation, v.18, p.79-86, 1997.

SMITH, W.H. Reduction of low-temperature injury to storage life and fruit quality in controlled atmospheres and storage. Journal of American Society for Horticultural Science, v.113, n.5, p.723-728, 1958.

TAIZ, L.; ZEIGER, E. Plant Phisiology 2.ed. Massachusetts: Sinauer Associates Publishers, 1998. 792p.

THÉ, P.M.P. Efeitos da associação de tratamento hidrotérmico, cloreto de cálcio e atmosfera sobre o escurecimento interno e qualidade do abacaxi 'Smooth Cayenne' . Lavras, 2001. 128p. Tese (Doutorado) - Universidade Federal de Lavras.

TUCKER, G.A. Introduction. In:SEYMOUR, G.B.; TAYLOR, J.E.; TUCKER, G.A. Biochemistry of fruit ripening. London: Chapmal \& Hall, 1993. cap.1,p.2-51.

VON MOLLENDORFF, L.J.; DE VILLIERS, O.T. Physiological changes associated with the development of woolliness in 'Peregrine' peaches during low temperature storage. Journal of Horticultural Science. v.63, p.47-51, 1988a.

VON MOLLENDORFF, L.J.; DE VILLIERS, O.T. Role of pectol.ytic enzymes in the development of woolliness in peaches. Journal of Horticultural Science. v.63, p.8$53,1988 b$.

WANG, C.Y. Approaches to reduce chilling injury of fruits and vegetables. Horticultural Reviews, v.15, p.63-95, 1993.

WANG, C.Y. Combined treatment of heat shock and low temperature conditioning reduces chilling injury in zucchini squash. Postharvest Biology and Technology, v.4, p.65-73, 1994. 
WHANGCHAI, K.; GEMMA, H. Endogenous polyamines in 'Nam Dok Mai' mangoes with different ripening stages and its relation to chilling injury during storage. Acta Horticulturae, v.509, p.429-433, 2000.

WILLS, R.H.H.; LEE, T.H.; GRAHAM, W.B.; HALL, E.G. Postharvest- an introduction to the physiology and handling of fruit and vegetables. Kensington: New South Wales University Press, 1981. 161p.

WILLS, R.H.H.; McGLASSON, B.; GRAHAM, D.; JOYCE, D. Introducción a la fisiología y manipulación poscosecha de frutas, horatizas y plantas ornamentales. 2.ed. Trad. de j.b. Gonzáles. Zaragoza: Acribia, 1998. 240p.

WOOLF, A.B.; LAY-YEE, M. Pretreatments at $38^{\circ} \mathrm{C}$ of 'Hass' avocado confer thermotolerance to $50^{\circ} \mathrm{C}$ hot water treatments. HortScience, v.32, p.705-708, 1997.

YANG, S.F. Biosynthesis and action of ethylene. HortScience, v.20, n.1, p.41-45, 1985.

YU, Y.B.; ADAMS, D.O.; YANG, S.F. Inhibition of ethylene production by 2,4dinitrophenol and high temperature. Plant Physiology, v.66, n.2, p.286-290, 1980.

ZHOU, H.; BEN-AIRE, R.; LURIE, S. Pectin esterase, polygalacturonase and gel formation in peach pectin fractions. Phytochemistry, n.55, p.191-195, 2000a.

ZHOU, H.W.; DONG, L.; BEN-AIRE, R.; LURIE, S. The role of ethylene in the prevention of chilling injury in nectarines. Journal of Plant Physiology, v.158, p.55$61,2001$.

ZHOU, T., SHIYING, X.; SUN D.; WANG, Z. Effects of heat treatment on postharvest quality of peaches. Journal of Food Engineering, n.54, p.17-23, 2002.

ZHOU, H.; LURIE, S.; LERS, A.; KHATCHITSKI, A.; SONEGO, L.; BEN-AIRE, R. Delayed storage and controlled atmosphere storage of nectarines: two strategies to prevent woolliness. Postharvest Biology and Technology, v.18, p.133-141, 2000b. http://www.itupeva.sp.gov.br/clima.htm (9 set.2004). 